\title{
Parametric Study for Thermal and Catalytic Methane Pyrolysis for Hydrogen Production: Techno-Economic and Scenario Analysis
}

\author{
Seunghyun Cheon ${ }^{1,+}$, Manhee Byun ${ }^{1,+}$, Dongjun Lim ${ }^{1}$, Hyunjun Lee ${ }^{1}$ and Hankwon Lim ${ }^{1,2, *}$ \\ 1 School of Energy and Chemical Engineering, Ulsan National Institute of Science and Technology (UNIST), \\ 50 UNIST-gil, Eonyang-eup, Ulju-gun, Ulsan 44919, Korea; tsi03075@unist.ac.kr (S.C.); \\ qusaksgml@unist.ac.kr (M.B.); dongjun1993@unist.ac.kr (D.L.); owl12@unist.ac.kr (H.L.) \\ 2 Department of Energy Engineering, Ulsan National Institute of Science and Technology (UNIST), \\ 50 UNIST-gil, Eonyang-eup, Ulju-gun, Ulsan 44919, Korea \\ * Correspondence: hklim@unist.ac.kr; Tel.: +82-52-217-2935 \\ + These authors contributed equally to this paper.
}

check for updates

Citation: Cheon, S.; Byun, M.; Lim, D.; Lee, H.; Lim, H. Parametric Study for Thermal and Catalytic Methane Pyrolysis for Hydrogen Production: Techno-Economic and Scenario Analysis. Energies 2021, 14, 6102. https://doi.org/10.3390/en14196102

Academic Editor: Dmitri A. Bulushev

Received: 13 August 2021

Accepted: 16 September 2021

Published: 24 September 2021

Publisher's Note: MDPI stays neutral with regard to jurisdictional claims in published maps and institutional affiliations.

Copyright: (c) 2021 by the authors. Licensee MDPI, Basel, Switzerland. This article is an open access article distributed under the terms and conditions of the Creative Commons Attribution (CC BY) license (https:// creativecommons.org/licenses/by/ $4.0 /)$.
Abstract: As many countries have tried to construct a hydrogen $\left(\mathrm{H}_{2}\right)$ society to escape the conventional energy paradigm by using fossil fuels, methane pyrolysis (MP) has received a lot of attention owing to its ability to produce $\mathrm{H}_{2}$ with no $\mathrm{CO}_{2}$ emission. In this study, a techno-economic analysis including a process simulation, itemized cost estimation, and sensitivity and scenario analysis was conducted for the system of thermal-based and catalyst-based MP (TMP-S1 and CMP-S2), and the system with the additional $\mathrm{H}_{2}$ production processes of carbon $(\mathrm{C})$ gasification and water-gas shift (WGS) reaction (TMPG-S3 and CMPG-S4). Based on the technical performance expressed by $\mathrm{H}_{2}$ and $\mathrm{C}$ production rate, the ratio of $\mathrm{H}_{2}$ combusted to supply the heat required and the ratio of reactants for the gasifier $\left(\mathrm{C}\right.$, Air, and water $\left.\left(\mathrm{H}_{2} \mathrm{O}\right)\right)$, unit $\mathrm{H}_{2}$ production costs of USD 2.14, 3.66, 3.53, and $3.82 \mathrm{kgH}_{2}{ }^{-1}$ from TMP-S1, CMP-S2, TMPG-S3, and CMPG-S4, respectively, were obtained at $40 \%$ $\mathrm{H}_{2}$ combusted and a reactants ratio for $\mathrm{C}-\mathrm{Air}-\mathrm{H}_{2} \mathrm{O}$ of 1:1:2. Moreover, trends of unit $\mathrm{H}_{2}$ production cost were obtained and key economic parameters of the MP reactor, reactant, and $\mathrm{C}$ selling price were represented by sensitivity analysis. In particular, economic competitiveness compared with commercialized $\mathrm{H}_{2}$ production methods was reported in the scenario analysis for the $\mathrm{H}_{2}$ production scale and $\mathrm{C}$ selling price.

Keywords: thermal methane pyrolysis; catalytic methane pyrolysis; $\mathrm{H}_{2}$ production; process simulation; economic analysis; unit $\mathrm{H}_{2}$ production cost

\section{Introduction}

Many countries have tried to accomplish a successful transition of an energy system to hydrogen $\left(\mathrm{H}_{2}\right)$ based on various political strategies such as 'The National Hydrogen Strategy' (2020) in Germany [1], 'EU Hydrogen Strategy' (2020) in the EU [2], 'Basic Hydrogen Strategy' (2017)', 'Strategic Energy Plan' (2018), and 'The Strategic Road Map for Hydrogen and Fuel Cells' (2019) in Japan [3-5], 'Hydrogen in a Low-carbon Economy' (2018) in the UK [6], 'H $\mathrm{H}_{2} @ S c a l$ ' $^{\prime}$ (2021) in USA [7], and 'National Hydrogen Roadmap' (2018) in Australia [8]. These active approaches to an $\mathrm{H}_{2}$-based energy system come from the diverse advantages of $\mathrm{H}_{2}$ as a clean energy carrier: it can be utilized in various energy sectors and easily combined in already constructed infrastructure, and, even though its volumetric energy density is relatively low, it shows a very high energy density of $120-142 \mathrm{MJ} \mathrm{kg}^{-1}$ in the compressed state [9-15]. For the conventional production of $\mathrm{H}_{2}$, energy-intensive processes such as reforming, partial oxidation, and auto-thermal reforming of carbon-based fuels such as methane $\left(\mathrm{CH}_{4}\right)$ and hydrocarbon have been mainly used. However, these conventional methods, including steam methane reforming (SMR), have led to negative environmental effects due to large emissions of carbon dioxide $\left(\mathrm{CO}_{2}\right)$ [16-19]. Due to the 
environmental issues of conventional methods, a lot of recent research has suggested water electrolysis (WE) powered by renewable energy as an alternative eco-friendly solution to produce $\mathrm{H}_{2}$ because there is no $\mathrm{CO}_{2}$ emission in the procedure [20-22]. However, there are still technical and economic challenges to be immediately utilized [23-25]; most $\mathrm{H}_{2}$ production still depends on conventional methods with additional processes to reduce $\mathrm{CO}_{2}$ such as SMR with $\mathrm{CO}_{2}$ capture and storage (SMR with CCS) [26-28].

To overcome the limitations of current $\mathrm{H}_{2}$ production methods, the concept of thermal methane pyrolysis (TMP), where $\mathrm{H}_{2}$ and carbon (C) are directly produced in the gas phase (Equation (1)), has been paid attention as an alternative, novel $\mathrm{H}_{2}$ production method owing to several technical, economic, and environmental benefits as follows: (a) there is no oxygen $\left(\mathrm{O}_{2}\right)$ in the reaction leading to no $\mathrm{CO}_{2}$ emissions or additional separation process, theoretically; (b) the process can be relatively simplified and lower energy is required than other methods such as reforming or partial oxidation; (c) reactant of the process, methane, is abundant and cheap leading to a cost effective operation of the process; (d) C products can be marketed because they are usually used as raw materials in various valuable materials such as rubber, tires, and pigments, etc.; (e) the separation of $\mathrm{C}$ is much easier than the separation of $\mathrm{CO}_{2} ;$ (f) it requires a lower amount of heat compared to SMR (Equation (2a-c)) and WE (Equation (3)), which are the most common and novel $\mathrm{H}_{2}$ production methods (Equations (1)-(3)) [29-38].

$$
\begin{array}{ll}
\mathrm{CH}_{4} \rightarrow 2 \mathrm{H}_{2}+\mathrm{C}(\mathrm{s}) & \Delta \mathrm{H}^{\circ}=75 \mathrm{~kJ} \mathrm{~mol}^{-1} \\
\mathrm{CH}_{4}+\mathrm{H}_{2} \mathrm{O} \rightarrow 3 \mathrm{H}_{2}+\mathrm{CO} & \Delta \mathrm{H}^{\circ}=206 \mathrm{~kJ} \mathrm{~mol}^{-1} \\
\mathrm{CO}+\mathrm{H}_{2} \mathrm{O} \rightarrow \mathrm{H}_{2}+\mathrm{CO}_{2} & \Delta \mathrm{H}^{\circ}=-41 \mathrm{~kJ} \mathrm{~mol}^{-1} \\
\mathrm{CH}_{4}+2 \mathrm{H}_{2} \mathrm{O} \rightarrow 4 \mathrm{H}_{2}+\mathrm{CO}_{2} & \Delta \mathrm{H}^{\circ}=165 \mathrm{~kJ} \mathrm{~mol}^{-1} \\
\mathrm{H}_{2} \mathrm{O} \rightarrow \mathrm{H}_{2}+\frac{1}{2} \mathrm{O}_{2} & \Delta \mathrm{H}^{\circ}=285 \mathrm{~kJ} \mathrm{~mol}^{-1}
\end{array}
$$

Because of its endothermicity and strong $\mathrm{C}-\mathrm{H}$ bonding, TMP is usually operated at over $1373 \mathrm{~K}$ to obtain reasonable yields of $\mathrm{H}_{2}$ and $\mathrm{C}$ leading to cost ineffectiveness and a large amount of energy being required $[39,40]$. These problems of having to use high temperature can be reduced by catalytic methane pyrolysis (CMP) where various types of catalysts (non-supported, metal supported, metal oxide supported, and carbonaceous, etc.) are adopted. Among the various catalysts used in CMP, the metal-based catalyst has very critical systematic limitations such as high toxicity of metal and rapid deactivation of the catalyst due to encapsulation of the active metal sites with $C$ product [41]. Thus, carbon-based CMP has a lot of attention owing to the properties of carbon catalysts such as lower cost, higher stability, temperature resistance, and their ability to be safely stored due to their non-toxicity.

Based on the benefits of the concept of MP, many kinds of research have been conducted: Nishii et al. [42] carried out MP with different carbon-based catalysts (activated carbon, carbon black, mesoporous carbon, and carbon nanofiber) and found that all of these catalysts continued to maintain a $\mathrm{CH}_{4}$ conversion of about $17 \%$ for longer than $600 \mathrm{~min}$ by catalyzing the produced $C$. It was reported that the produced $C$ covered the catalyst surface, resulting in a specific surface area of $10 \mathrm{~m}^{2} \mathrm{~g}^{-1}$ and an intensity of D-Raman peak and G-Raman peak $\left(\mathrm{I}_{\mathrm{d}} / \mathrm{I}_{\mathrm{g}}\right)$ from 1.5 to 1.57 irrespective of the original structures of $\mathrm{C}$. Tezel et al. [43] designed an experiment using CMP with a calcium silicate-based Ni-Fe catalyst with different Fe loading by using the co-impregnation method. It was revealed that the addition of Fe can delay the deactivation of the Ni catalyst and an increase in the $\mathrm{CH}_{4}$ flow rate can decrease the initial reactant conversion and lifetime of the catalyst. It was reported that the highest methane conversion of $69 \%$ is obtained at $973 \mathrm{~K}$ with the catalyst that has the highest Fe addition. Quan et al. [44] investigated the optimization of a fluidized bed reactor (FLBR) for CMP using $40 \mathrm{wt} \% \mathrm{Fe} / \mathrm{Al}_{2} \mathrm{O}_{3}$ catalyst, and catalyst activity and stability were investigated after optimization in terms of the catalyst bulk density, bed height, and particle size, etc. It was reported that the reaction conditions of $12 \mathrm{~L}\left(\mathrm{~g}_{\text {cat }} \mathrm{h}\right)^{-1}$ feed dilution of $20 \% \mathrm{H}_{2}-\mathrm{CH}_{4}$, and $\mathrm{CO}_{2}$-regeneration of deactivated catalysts are the best conditions for MP. Patzschke et al. [45] investigated promising catalysts for particle suspension in molten 
$\mathrm{NaBr}-\mathrm{KBr}$ and reported that mixed $\mathrm{Co}-\mathrm{Mn}$ catalysts can be optimal candidates for methane pyrolysis in molten salts owing to their fast kinetics and stability. The authors reported that increasing the ratio of molar Co-Mn from 0 to 2 improved the conversion of $\mathrm{CH}_{4}$ from $4.8 \%$ to $10.4 \%$ at $1273 \mathrm{~K}$ for the smallest catalyst particle size range, which shows that closeness between the catalytic surface and the gas phase can improve conversions. Karaismailoglu et al. [46] investigated the effect of the doping of yttria on a nickel catalyst synthesized by the sol-gel citrate method and reported $\mathrm{CH}_{4}$ conversion of $50 \%$ with this type of catalyst. It was reported that the addition of Yttria can improve the stability and activity of catalysts at elevated temperatures and that a lower nickel ratio in the catalyst reduces the formation of carbon. Not only experimental studies but also systematic approaches using process simulations and works for economic feasibility have been reported. Chen et al. [47] designed the vacuum promoted methane decomposition with carbon separation (VPMDCS), which include a reactor of MP continuously generating $\mathrm{H}_{2}$ and a $\mathrm{C}$ separation reactor converting carbon into CO. It was reported that VPMDCS showed $\mathrm{CH}_{4}$ conversion of $99.2 \%$ and produced high-purity $\mathrm{H}_{2}$ and $\mathrm{CO}$ with concentrations of both $99.6 \%$. By economic analysis, the unit hydrogen cost of EUR $5.4 \mathrm{~kg}^{-1}$ was reported. Riley et al. [48] simulated two concepts of $\mathrm{CMP}$ that used $\mathrm{H}_{2}$ combustion and $\mathrm{CH}_{4}$ combustion by Aspen Plus ${ }^{\circledR}$ comparing $\mathrm{CO}_{2}$ emissions and $\mathrm{H}_{2}$ production cost. It was revealed that the quality of produced $\mathrm{C}$ and its selling price are major factors in $\mathrm{H}_{2}$ selling price, and $\mathrm{H}_{2}$ production cost in the capacity of 216 ton $\mathrm{d}^{-1}$ is less than USD $3.25 \mathrm{kgH}_{2}{ }^{-1}$ without considering the sale of C. Perez et al. [49] designed an MP process using a quartz bubble column including molten gallium, which is used for catalyst and heat transfer agents, with a porous plate distributor. The authors found that a maximum $\mathrm{CH}_{4}$ conversion of $91 \%$ was achieved at a reactor temperature of $1392 \mathrm{~K}$ where gallium occupied $43 \%$ of the total reactor volume with a residence time for a bubble of $0.5 \mathrm{~s}$. Additionally, by techno-economic analysis, it was concluded that a molten metal system can be competitive with $\mathrm{SMR}$ if a $\mathrm{CO}_{2}$ tax of EUR 50 ton $^{-1}$ is imposed and produced C is marketed. Kerscher et al. [50] designed two concepts of MP using electron beam plasma, which was generated from renewable electricity. The techno-economic assessment reported that levelized costs of $\mathrm{H}_{2}$ for the electron beam plasma method ranged from 2.55 to $5.00 € \mathrm{kgH}_{2}{ }^{-1}$, and $\mathrm{CO}_{2}$ emission ranged from 1.9 to $6.4 \mathrm{kgCO}_{2}$ eq. $\mathrm{kgH}_{2}{ }^{-1}$ from a carbon footprint assessment, which shows a high potential for reducing life cycle emissions. Zhang et al. [51] investigated the $\mathrm{CO}_{2}$ mitigation costs of CMP and the integrated power generation process in a fuel cell comparing a combined-cycle gas turbine power plant system with and without CCS. It was revealed that CMP shows low life cycle emissions per unit of electricity output of $0.13 \mathrm{tCO}_{2} \mathrm{eq}$ $\mathrm{MWh}^{-1}$ but shows a high levelized cost of electricity of EUR $177 \mathrm{MWh}^{-1}$, concluding that it has high potential when assumed that produced $C$ can be sold at current prices. Timmerberg et al. [52] assessed the levelized hydrogen production costs and life cycle greenhouse gas (GHG) emissions from MP in three systems where molten metal, plasma, and thermal gas reactors were used. It was reported that the plasma-based system using electricity from renewable sources shows the lowest emissions of $43 \mathrm{gCO}_{2} \mathrm{MJ}^{-1}$, and the molten metal and thermal gas system shows relatively higher GHG emissions due to the additional combustion and natural gas supply chain.

Even though many types of research have been conducted on the concepts of TMP and CMP, very few studies revealing both technical and economic viability of those technologies are reported, to the best of our knowledge. Therefore, in this study, a preliminary technoeconomic parametric study is conducted to comprehensively investigate the feasibility of the concept of methane pyrolysis (MP). Firstly, a process simulation using Aspen Plus ${ }^{\circledR}$ for various MP processes, namely TMP and CMP, and with additional carbon gasification (TMPG and CMPG) are performed with detailed reaction kinetics under various technical parameters of reaction temperature, ratio of fuel combusted, and ratio of reactants for gasifier (C-Air- $\mathrm{H}_{2} \mathrm{O}$ ) (Figure 1). Based on the technical performance from the process simulation, yields of $\mathrm{H}_{2}$ and $\mathrm{C}$, and the amount of fuel required to supply heat to the MP reactor and gasification unit are obtained, and then, economic feasibility in terms of unit $\mathrm{H}_{2}$ 
production cost is reported. In addition, to suggest future economic guidelines of this novel concept when this is commercialized, sensitivity and scenario analysis regarding various $\mathrm{H}_{2}$ production scales and different $\mathrm{C}$ selling price scenarios are conducted revealing the cost competitiveness compared to the conventional $\mathrm{H}_{2}$ production methods of SMR and SMR with CCS.

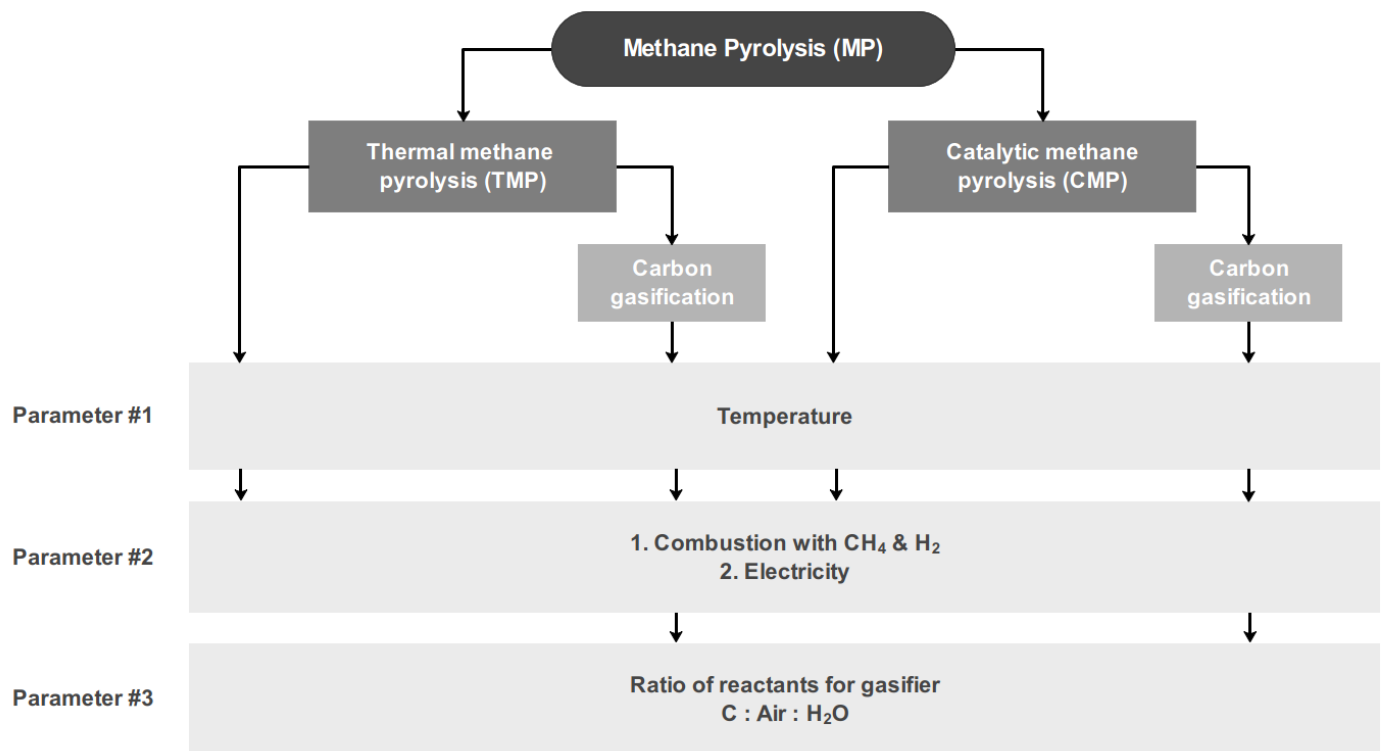

Figure 1. Schematic diagram of techno-economic parametric study for investigated systems for methane pyrolysis (MP).

\section{Methods}

\subsection{Process Simulation}

In this study, four systems for MP, classified as TMP-S1, CMP-S2, TMPG-S3, and CMPG-S4, were simulated in Aspen Plus ${ }^{\circledR}$ (Aspen Technology, Inc., Bedford, MA, USA) with detailed reactor validation based on kinetics reported by Keipi et al. [53] for TMP and Kim et al. [54] for CMP. As a result, Figure 2 shows the closeness of methane conversion between experimental and simulated methods at each investigated operating conditions validating proper insertion of reported kinetics to Aspen Plus ${ }^{\circledR}$.

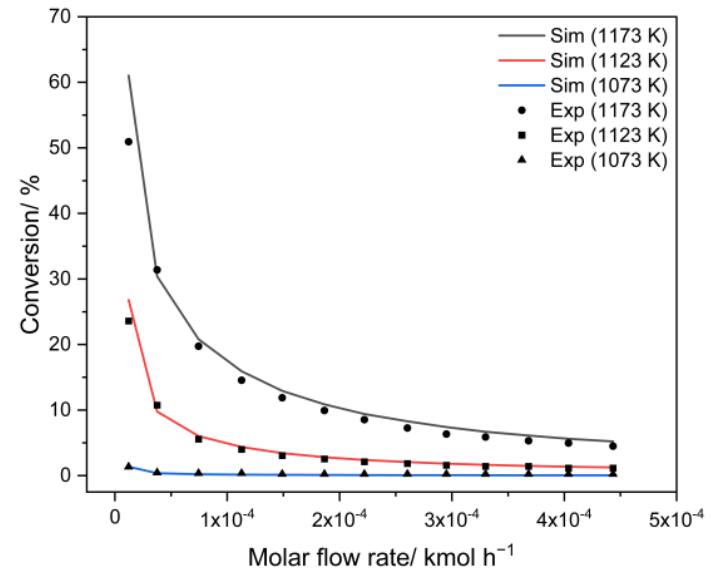

(a)

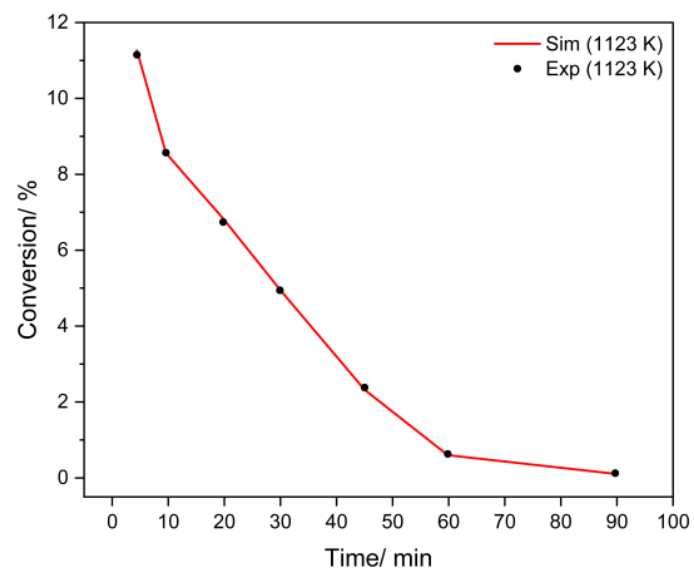

(b)

Figure 2. Results of kinetic validation for (a) thermal methane pyrolysis (TMP) and (b) catalytic methane pyrolysis $(\mathrm{CMP})$ reactions. 
For all systems, $\mathrm{CH}_{4}$ entered the validated reactor in different temperature ranges of 1073-1373 K for TMP-S1 and TMPG-S3, and 1023-1173 K for CMP-S2 and CMPG-S4, then, product stream containing remained $\mathrm{CH}_{4}$ and produced $\mathrm{H}_{2}$ and $\mathrm{C}$ passed through the units of cyclone and pressure swing adsorption (PSA) for separating solid $\mathrm{C}$ and $\mathrm{H}_{2}$, respectively (Figure 3). We assumed the pressure drop of cyclone as 0.01 bar and number of cyclones as only one and assumed separation efficiency of PSA as $100 \%$. Especially for CMP-S2 and CMPG-S4, purified C entered the gasification unit to produce additional $\mathrm{H}_{2}$ and carbon monoxide $(\mathrm{CO})$ with different ratios of $\mathrm{C}$, air, and water $\left(\mathrm{H}_{2} \mathrm{O}\right)(1: 1: 1,1: 1: 2,1: 1: 3$, 1:2:1, and 1:3:1), and water-gas shift (WGS) (Equation (2b)) reactor was followed to convert the produced $\mathrm{CO}$ to $\mathrm{H}_{2}$. Additionally, for the heat supply system, various heat supply scenarios were assumed and classified as $100 \%$ electricity-based and different ratios of $\mathrm{H}_{2}$ combusted ( $0 \%-100 \%$ matched with $100 \%-0 \% \mathrm{CH}_{4}$ combusted). Based on the result of the process simulation, material balance was obtained at the temperature of $1273 \mathrm{~K}$ for TMP-S1 and TMPG-S3 and $1173 \mathrm{~K}$ for CMP-S2 and CMPG-S4, with the ratio of $\mathrm{H}_{2}$ combusted of $40 \%$, and the ratio of reactants for the gasifier of 1:1:2 (C-Air- $\left.\mathrm{H}_{2} \mathrm{O}\right)$ (Table 1).

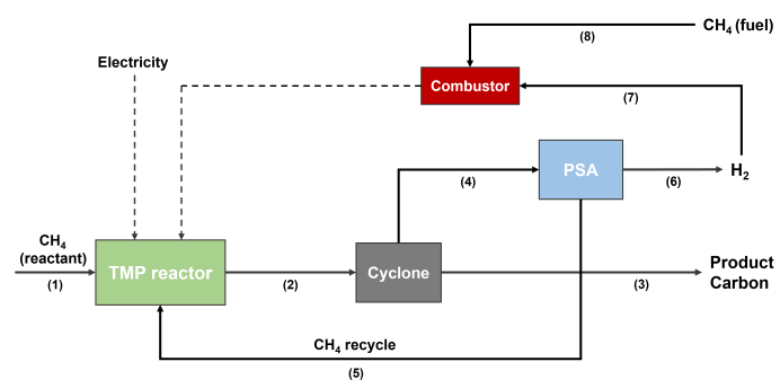

(a)

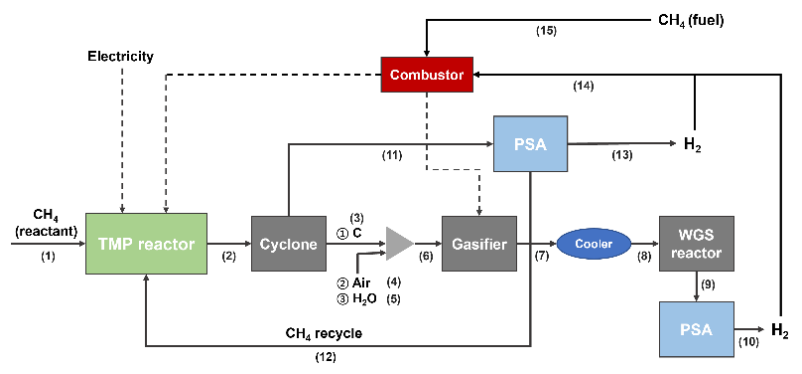

(c)

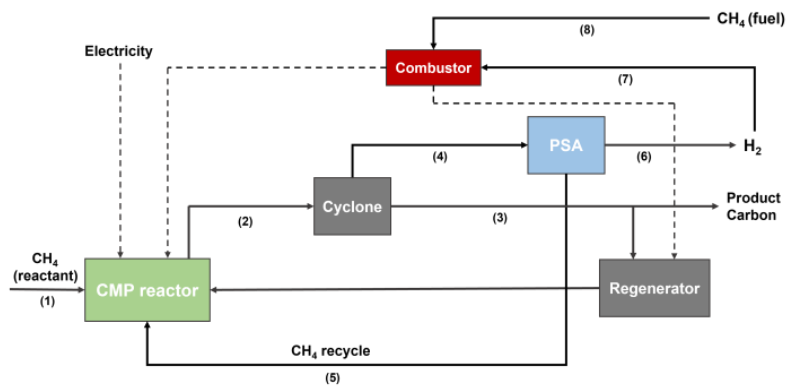

(b)

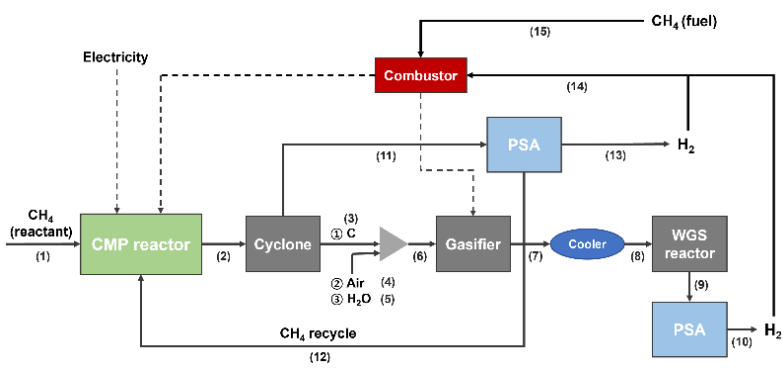

(d)

Figure 3. Block flow diagrams for methane pyrolysis (MP) systems of (a) thermal methane pyrolysis (TMP-S1), (b) catalytic methane pyrolysis (CMP-S2), and systems with additional gasification and WGS reaction of (c) TMPG-S3 and (d) CMPG-S4.

Table 1. Material balance for methane pyrolysis (MP) systems of (a) thermal methane pyrolysis (TMP-S1), (b) catalytic methane pyrolysis (CMP-S2), and systems with additional gasification and WGS reaction of (c) TMPG-S3 and (d) CMPG-S4.

\begin{tabular}{|c|c|c|c|c|c|c|c|c|}
\hline (a) TMP-S1 & $(1)$ & $(2)$ & (3) & $(4)$ & (5) & (6) & (7) & (8) \\
\hline Temperature/K & 298 & 1273 & 1273 & 1273 & 1273 & 1273 & 1273 & 298 \\
\hline Pressure/bar & 1.00 & 1.00 & 1.00 & 0.99 & 0.99 & 0.99 & 0.99 & 1.00 \\
\hline $\begin{array}{l}\text { Molar flow } / \mathrm{kmol} \mathrm{h}^{-1} \\
\text { Mole fraction }\end{array}$ & 1.00 & 3.02 & 1.00 & 2.02 & 0.02 & 2.00 & 0.27 & 0.12 \\
\hline $\mathrm{CH}_{4}$ & 1.00 & 0.01 & 0 & 0.01 & 1.00 & 0 & 0 & 1.00 \\
\hline $\mathrm{C}$ & 0 & 0.33 & 1.00 & 0 & 0 & 0 & 0 & 0 \\
\hline $\mathrm{H}_{2}$ & 0 & 0.66 & 0 & 0.99 & 0 & 1.00 & 1.00 & 0 \\
\hline
\end{tabular}


Table 1. Cont.

\begin{tabular}{|c|c|c|c|c|c|c|c|c|}
\hline (b) CMP-S2 & (1) & (2) & (3) & (4) & (5) & (6) & (7) & (8) \\
\hline Temperature/K & 298 & 1173 & 1173 & 1173 & 1173 & 1173 & 1173 & 298 \\
\hline Pressure/bar & 1.00 & 1.00 & 1.00 & 0.99 & 0.99 & 0.99 & 0.99 & 1.00 \\
\hline Molar flow $/ \mathrm{kmol} \mathrm{h}^{-1}$ & 1.00 & 5.27 & 0.93 & 4.34 & 2.42 & 1.85 & 0.24 & 0.11 \\
\hline \multicolumn{9}{|l|}{ Mole fraction } \\
\hline $\mathrm{CH}_{4}$ & 1.00 & 0.48 & 0 & 0.57 & 1.00 & 0 & 0 & 1.00 \\
\hline $\mathrm{C}$ & 0 & 0.18 & 1.00 & 0 & 0 & 0 & 0 & 0 \\
\hline $\mathrm{H}_{2}$ & 0 & 0.35 & 0 & 0.43 & 0 & 1.00 & 1.00 & 0 \\
\hline (c) TMPG-S3 & (1) & $(2)$ & (3) & (4) & (5) & (6) & (7) & (8) \\
\hline Temperature/K & 298 & 1273 & 1273 & 298 & 298 & 341 & 973 & 623 \\
\hline Pressure/bar & 1.00 & 1.00 & 1.00 & 1.00 & 1.00 & 1.00 & 1.00 & 1.00 \\
\hline Molar flow $/ \mathrm{kmol} \mathrm{h}^{-1}$ & 1.00 & 3.02 & 1.00 & 1.00 & 2.00 & 4.00 & 3.78 & 3.78 \\
\hline \multicolumn{9}{|l|}{ Mole fraction } \\
\hline $\mathrm{CH}_{4}$ & 1.00 & 0.01 & 0 & 0 & 0 & 0 & 0 & 0 \\
\hline C & 0 & 0.33 & 1.00 & 0 & 0 & 0.25 & 0 & 0 \\
\hline $\mathrm{H}_{2}$ & 0 & 0.66 & 0 & 0 & 0 & 0 & 0.30 & 0.30 \\
\hline $\mathrm{O}_{2}$ & 0 & 0 & 0 & 0.21 & 0 & 0.05 & 0 & 0 \\
\hline $\mathrm{H}_{2} \mathrm{O}$ & 0 & 0 & 0 & 0 & 1.00 & 0.50 & 0.23 & 0.23 \\
\hline $\mathrm{N}_{2}$ & 0 & 0 & 0 & 0.79 & 0 & 0.20 & 0.21 & 0.21 \\
\hline $\mathrm{CO}_{2}$ & 0 & 0 & 0 & 0 & 0 & 0 & 0.15 & 0.15 \\
\hline $\mathrm{CO}$ & 0 & 0 & 0 & 0 & 0 & 0 & 0.12 & 0.12 \\
\hline (c) TMPG-S3 & (9) & $(10)$ & (11) & (12) & (13) & (14) & (15) & \\
\hline Temperature/K & 623 & 623 & 1273 & 1273 & 1273 & 1273 & 298 & \\
\hline Pressure/bar & 1.00 & 1.00 & 0.99 & 0.99 & 0.99 & 0.99 & 1.00 & \\
\hline Molar flow $/ \mathrm{kmol} \mathrm{h}^{-1}$ & 3.78 & 1.38 & 2.02 & 0.02 & 2.00 & 0.45 & 0.20 & \\
\hline \multicolumn{9}{|l|}{ Mole fraction } \\
\hline $\mathrm{CH}_{4}$ & 0 & 0 & 0.01 & 1.00 & 0 & 0 & 1.00 & \\
\hline C & 0 & 0 & 0 & 0 & 0 & 0 & 0 & \\
\hline $\mathrm{H}_{2}$ & 0.36 & 1.00 & 0.99 & 0 & 1.00 & 1.00 & 0 & \\
\hline $\mathrm{O}_{2}$ & 0 & 0 & 0 & 0 & 0 & 0 & 0 & \\
\hline $\mathrm{H}_{2} \mathrm{O}$ & 0.16 & 0 & 0 & 0 & 0 & 0 & 0 & \\
\hline $\mathrm{N}_{2}$ & 0.21 & 0 & 0 & 0 & 0 & 0 & 0 & \\
\hline $\mathrm{CO}_{2}$ & 0.21 & 0 & 0 & 0 & 0 & 0 & 0 & \\
\hline $\mathrm{CO}$ & 0.05 & 0 & 0 & 0 & 0 & 0 & 0 & \\
\hline (d) CMPG-S4 & $(1)$ & $(2)$ & (3) & $(4)$ & (5) & (6) & (7) & (8) \\
\hline Temperature/K & 298 & 1173 & 1173 & 298 & 298 & 337 & 923 & 623 \\
\hline Pressure/bar & 1.00 & 1.00 & 1.00 & 1.00 & 1.00 & 1.00 & 1.00 & 1.00 \\
\hline Molar flow $/ \mathrm{kmol} \mathrm{h}^{-1}$ & 1.00 & 5.08 & 0.92 & 0.92 & 1.84 & 3.68 & 3.45 & 3.45 \\
\hline \multicolumn{9}{|l|}{ Mole fraction } \\
\hline $\mathrm{CH}_{4}$ & 1.00 & 0.46 & 0 & 0 & 0 & 0 & 0 & 0 \\
\hline $\mathrm{C}$ & 0 & 0.18 & 1.00 & 0 & 0 & 0.25 & 0 & 0 \\
\hline $\mathrm{H}_{2}$ & 0 & 0.36 & 0 & 0 & 0 & 0 & 0.30 & 0.30 \\
\hline $\mathrm{O}_{2}$ & 0 & 0 & 0 & 0.21 & 0 & 0.05 & 0 & 0 \\
\hline $\mathrm{H}_{2} \mathrm{O}$ & 0 & 0 & 0 & 0 & 1.00 & 0.50 & 0.22 & 0.22 \\
\hline $\mathrm{N}_{2}$ & 0 & 0 & 0 & 0.79 & 0 & 0.20 & 0.21 & 0.21 \\
\hline $\mathrm{CO}_{2}$ & 0 & 0 & 0 & 0 & 0 & 0 & 0.16 & 0.16 \\
\hline $\mathrm{CO}$ & 0 & 0 & 0 & 0 & 0 & 0 & 0.10 & 0.10 \\
\hline (d) CMPG-S4 & (9) & (10) & $(11)$ & $(12)$ & (13) & (14) & (15) & \\
\hline Temperature/K & 623 & 623 & 1173 & 1173 & 1173 & 1173 & 298 & \\
\hline Pressure/bar & 1.00 & 1.00 & 0.99 & 0.99 & 0.99 & 0.99 & 1.00 & \\
\hline Molar flow $/ \mathrm{kmol} \mathrm{h}^{-1}$ & 3.45 & 1.29 & 4.16 & 2.24 & 1.84 & 0.40 & 0.18 & \\
\hline \multicolumn{9}{|l|}{ Mole fraction } \\
\hline $\mathrm{CH}_{4}$ & 0 & 0 & 0.56 & 1.00 & 0 & 0 & 1.00 & \\
\hline C & 0 & 0 & 0 & 0 & 0 & 0 & 0 & \\
\hline $\mathrm{H}_{2}$ & 0.37 & 1.00 & 0.44 & 0 & 1.00 & 1.00 & 0 & \\
\hline $\mathrm{O}_{2}$ & 0 & 0 & 0 & 0 & 0 & 0 & 0 & \\
\hline $\mathrm{H}_{2} \mathrm{O}$ & 0.15 & 0 & 0 & 0 & 0 & 0 & 0 & \\
\hline $\mathrm{N}_{2}$ & 0.21 & 0 & 0 & 0 & 0 & 0 & 0 & \\
\hline $\mathrm{CO}_{2}$ & 0.23 & 0 & 0 & 0 & 0 & 0 & 0 & \\
\hline $\mathrm{CO}$ & 0.03 & 0 & 0 & 0 & 0 & 0 & 0 & \\
\hline
\end{tabular}

\subsection{Itemized Cost Estimation}

To investigate the economic feasibility of each MP system, itemized cost estimation proposed by Turton et al. [55] was conducted considering various parameters of reaction temperature, types of fuel combusted and its ratio, and the ratio of reactant for gasifier. In this method, the unit $\mathrm{H}_{2}$ production cost $\left(\mathrm{USD} \mathrm{kgH}_{2}{ }^{-1}\right)$ is obtained from the sum of the total cost $\left(\mathrm{USD}^{-1}\right)$ divided by the total amount of $\mathrm{H}_{2}$ produced $\left(\mathrm{kg} \mathrm{y}^{-1}\right)$. In this study, the total cost is defined as annualized capital cost $\left(\mathrm{USD} \mathrm{y}^{-1}\right)$, which is estimated from original 
capital cost (USD) by applying capital recovery factor (CRF) as shown in Equation (4), and operating cost $\left(\mathrm{USD}^{-1}\right)$. Table 2 shows the list of these.

$$
\mathrm{CRF}=\frac{i(1+i)^{N}}{(1+i)^{N}-1}
$$

where $i$ is a discount rate and $N$ is an economic analysis period.

In addition, to properly estimate each capital cost, the six-tenth rule (Equation (5)) and concept of chemical engineering plant cost index (CEPCI) (Equation (6)) are applied to consider economics of scale and effects of inflation.

$$
C_{2}=C_{1}\left(\frac{S_{2}}{S_{1}}\right)^{0.6}
$$

where $C$ is an equipment cost (USD) and $S$ is a scale of the certain chemical process.

$$
C_{2}=C_{1}\left(\frac{I_{2}}{I_{1}}\right)
$$

\begin{tabular}{|c|c|}
\hline \multicolumn{2}{|c|}{ Economic Parameters } \\
\hline \multicolumn{2}{|r|}{ Capital Cost } \\
\hline MP reactor [56] & EUR $2740 \mathrm{k}$ \\
\hline WGS reactor [56] & EUR $59 \mathrm{k}$ \\
\hline Regenerator [57] & USD 12,112,138 \\
\hline Catalyst [58] & USD $1.138 \mathrm{~kg}^{-1}$ \\
\hline Gasifier [56] & EUR $211 \mathrm{k}$ \\
\hline PSA [59] & $\frac{\text { CEPCI }}{392.6} \times 1,510,000 \times\left(\frac{\text { inlet flow rate }}{500}\right)^{0.6}(\mathrm{USD})$ \\
\hline Cyclone [58] & USD 31,400 \\
\hline Supplement & $20 \%$ of (Capital cost-Supplement) (USD) \\
\hline \multicolumn{2}{|r|}{ Operating Cost } \\
\hline $\mathrm{CH}_{4}[60]$ & USD $0.005 \mathrm{MJ}_{\mathrm{LHV}^{-1}}$ \\
\hline Catalyst operating cost & Assumed as $10 \%$ loss per month \\
\hline Water [61] & USD 12 ton $^{-1}$ \\
\hline Electricity [32] & USD $56 \mathrm{MWh}^{-1}$ \\
\hline Labor [62] & USD $11 \mathrm{hr}^{-1}$ \\
\hline PSA operating cost [59] & $6.11 \times 100 \times\left(\right.$ inlet flow rate except $\left.\mathrm{H}_{2}\right)(\mathrm{USD})$ \\
\hline C selling price [63] & EUR 500 ton $^{-1}$ \\
\hline Maintenance [64] & $1 \%$ of (Capital cost-Supplement) $\left(\mathrm{USD}^{-1}\right)$ \\
\hline Other cost [64] & $2 \%$ of (Capital cost-Supplement) $\left(\mathrm{USD}^{-1}\right)$ \\
\hline \multicolumn{2}{|c|}{ Economic Assumptions } \\
\hline CEPCI (2021) & 655.9 \\
\hline$i$ & 0.045 \\
\hline Exchange rate & USD 1 = EUR 0.85 \\
\hline$N$ & $\begin{array}{c}20 \text { years for MP reactor } \\
10 \text { years for WGS reactor, regenerator, PSA, PSA operating cost, } \\
\text { cyclone, and supplement } \\
1 \text { year for catalyst }\end{array}$ \\
\hline Stream factor & 0.95 \\
\hline
\end{tabular}

where $C$ is an equipment cost (USD) and $I$ is a CEPCI.

Table 2. List of economic parameters and assumptions used in itemized cost estimation.

\subsection{Sensitivity and Scenario Analysis}

Key economic parameters of each system of MP and future unit $\mathrm{H}_{2}$ production cost with varied $C$ selling price, which can be advantages for economic feasibility, were quantita- 
tively investigated by sensitivity and scenario analysis, respectively. For sensitivity analysis, with varied capital and operating cost in a range of $\pm 20 \%$ with other parameters fixed, the degree of variation in unit $\mathrm{H}_{2}$ production cost for each MP system was investigated. In addition, trends of unit $\mathrm{H}_{2}$ production cost for each scenario according to different $\mathrm{H}_{2}$ production scales and $\mathrm{C}$ selling prices were obtained and compared to conventional $\mathrm{H}_{2}$ production methods of SMR and SMR with CCS.

\section{Results and Discussion}

\section{1. $\mathrm{H}_{2}$ and $\mathrm{C}$ Production Rates}

Based on the result of the process simulation, $\mathrm{H}_{2}$ and $\mathrm{C}$ production rates for each MP system with a feed $\mathrm{CH}_{4}$ rate of $1 \mathrm{kmol} \mathrm{h}^{-1}$ were obtained at the different operating temperatures of 1073-1373 K for TMP-S1 and TMPG-S3 and 1023-1173 K for CMP-S2 and CMPG-S4, with the ratio of $\mathrm{H}_{2}$ combusted of $0 \%-100 \%$, and the ratio of reactants composed of $\mathrm{C}$, Air, and $\mathrm{H}_{2} \mathrm{O}$ (Figure 4).

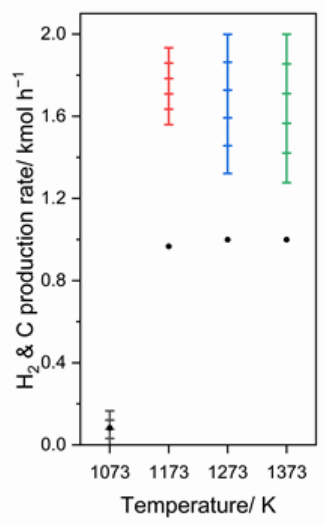

(a)

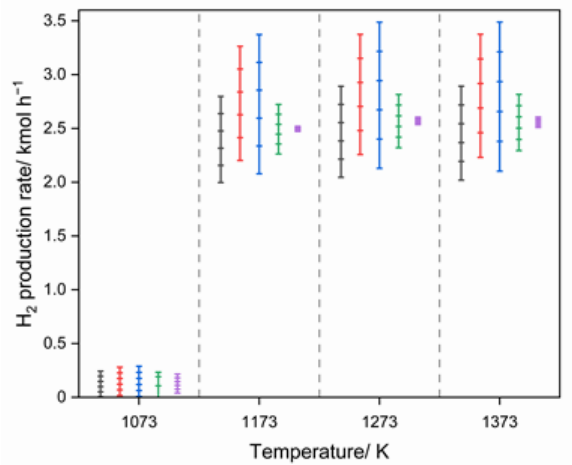

(c)

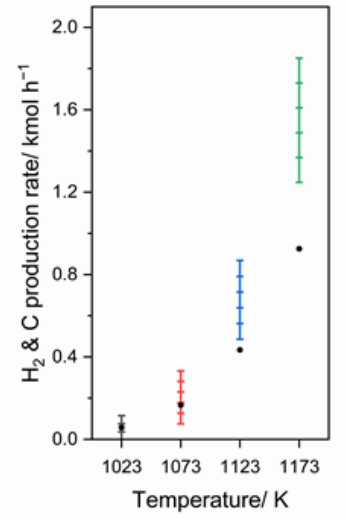

(b)

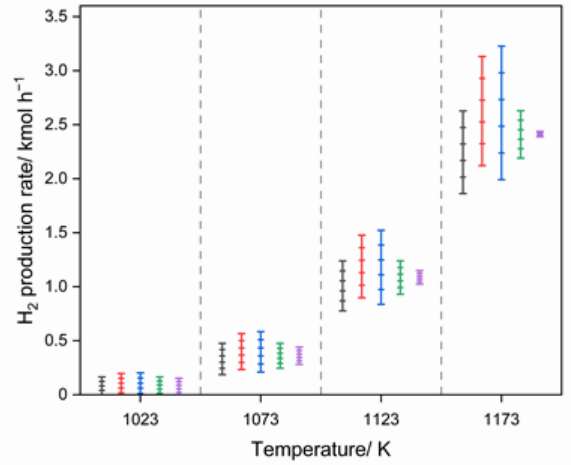

(d)

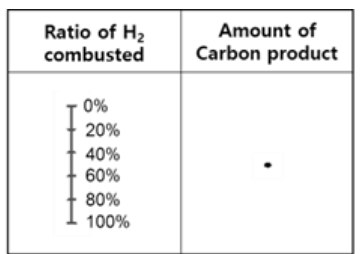

\begin{tabular}{|c|c|}
\hline $\begin{array}{c}\text { Ratio of } \mathrm{H}_{2} \\
\text { combusted }\end{array}$ & C:Air: $\mathrm{H}_{2} \mathrm{O}$ \\
\hline & \\
\hline & $0 \%$ \\
$20 \%$ & $-1: 1: 1$ \\
& \\
$40 \%$ & $1: 1: 2$ \\
$60 \%$ & $-1: 3$ \\
$-80 \%$ & $-1: 2: 1$ \\
$100 \%$ & - \\
\hline
\end{tabular}

Figure 4. Technical performance for methane pyrolysis (MP) systems of (a) thermal methane pyrolysis (TMP-S1), (b) catalytic methane pyrolysis (CMP-S2), and systems with additional gasification and WGS reaction of (c) TMPG-S3 and (d) CMPG-S4.

For TMP-S1 (Figure 4a), net $\mathrm{H}_{2}$ production rates of $0-0.17,1.56-1.93,1.32-2.00$, and $1.28-2.00 \mathrm{kmol} \mathrm{h}^{-1}$ and $\mathrm{C}$ production rates of $0.08,0.97,1.00$, and $1.00 \mathrm{kmol} \mathrm{h}^{-1}$ were obtained at a temperature of $1073 \mathrm{~K}, 1173 \mathrm{~K}, 1273 \mathrm{~K}$, and $1373 \mathrm{~K}$, respectively. As reaction temperature increased, the range of net $\mathrm{H}_{2}$ production rate was highly dependent on the ratio of $\mathrm{H}_{2}$ combusted due to the large amount of heat required and the different thermodynamic properties of each fuel, and produced $C$ was maximized from $1173 \mathrm{~K}$, not even the maximum investigated temperature.

For CMP-S2 (Figure 4b), 0.00-0.12, 0.08-0.33, 0.49-0.87, and $1.25-1.85 \mathrm{kmol} \mathrm{h}^{-1}$ for net $\mathrm{H}_{2}$ production rates and $0.06,0.17,0.43$, and $0.93 \mathrm{kmol} \mathrm{h}^{-1}$ for $\mathrm{C}$ production rates were obtained at temperatures of $1023 \mathrm{~K}, 1073 \mathrm{~K}, 1123 \mathrm{~K}$ and $1173 \mathrm{~K}$, respectively. Even though 
an increasing trend of $\mathrm{H}_{2}$ and $\mathrm{C}$ production rate and a high dependence of the ratio of $\mathrm{H}_{2}$ combusted was shown, which are similar to the results from TMP-S1, no theoretical maximum amounts of $\mathrm{H}_{2}$ and $\mathrm{C}$ ( 2 and $1 \mathrm{kmol} \mathrm{h}^{-1}$, respectively) were produced.

For TMPG-S3 (Figure 4c), even with the various ratios of $\mathrm{C}$, Air, and $\mathrm{H}_{2} \mathrm{O}$ for the gasification unit, very low $\mathrm{H}_{2}$ production rates of $0.00-0.29 \mathrm{kmol} \mathrm{h}^{-1}$ were obtained at $1073 \mathrm{~K}$. That poor technical performance, lower than the theoretical $\mathrm{H}_{2}$ production rate of $2 \mathrm{kmol} \mathrm{h}^{-1}$ for the previous system of TMP-S1, was raised by higher reaction temperatures of MP, leading to the improved technical performance of $2.00-3.49 \mathrm{kmol} \mathrm{h}^{-1} \mathrm{H}_{2}$ production rates at $1173-1373 \mathrm{~K}$. For the ratio of reactants in the gasifier, $\mathrm{H}_{2}$ production rates at $1373 \mathrm{~K}$ dramatically increased $2.02-2.89 \mathrm{kmol} \mathrm{h}^{-1}$ for a $1: 1: 1$ ratio to rates of $2.10-3.49 \mathrm{kmol} \mathrm{h}^{-1}$ for a ratio of 1:1:3, proving the importance of $\mathrm{H}_{2} \mathrm{O}$ in the additional $\mathrm{H}_{2}$ production processes of $\mathrm{C}$ gasification and the WGS reactor. Compared to the effect of $\mathrm{H}_{2} \mathrm{O}$ on net $\mathrm{H}_{2}$ production rates, an opposite effect of air was shown with decreased maximum $\mathrm{H}_{2}$ production rates of 2.81 and $2.61 \mathrm{kmol} \mathrm{h}^{-1}$ for the ratios of 1:2:1 and 1:3:1, respectively, down from $2.89 \mathrm{kmol}$ $\mathrm{h}^{-1}$ for a 1:1:1 ratio, thereby identifying its disadvantage in technical performance.

For CMPG-S4 (Figure 4d), lower $\mathrm{H}_{2}$ production rates of $0.00-0.20,0.19-0.58$, and $0.78-1.52 \mathrm{kmol} \mathrm{h}^{-1}$ were obtained than those from TMPG-S3 in a range of similar investigated temperatures (1073-1273 K). Even though the technical performance was improved at a higher reaction temperature of $1173 \mathrm{~K}$ showing $\mathrm{H}_{2}$ production rates of $1.86-3.23 \mathrm{kmol}$ $\mathrm{h}^{-1}$, this is still lower than those from TMPG-S3. For the effect of air and $\mathrm{H}_{2} \mathrm{O}$ on $\mathrm{H}_{2}$ production rates, similar trends to those for TMPG-S3 of increased rates from $1.86-2.63 \mathrm{kmol} \mathrm{h}^{-1}$ (1:1:1) to $1.99-3.23 \mathrm{kmol} \mathrm{h}^{-1}$ (1:3:1) and decreased rates from $2.19-2.63 \mathrm{kmol} \mathrm{h}^{-1}$ (1:2:1) to 2.39-2.44 $\mathrm{kmol} \mathrm{h}^{-1}$ (1:3:1).

As a result, through the trends of $\mathrm{H}_{2}$ and $\mathrm{C}$ production rates obtained from the process simulation, the detailed effects of temperature, the ratio of $\mathrm{H}_{2}$ combusted, and the ratio of reactants entering the gasifier were confirmed.

\subsection{Parametric Study-Fuel Consumption}

To investigate the amount of fuel combusted to cover the total heat required in each system, the required amount of fuel $\left(\mathrm{H}_{2}\right.$ and $\left.\mathrm{CH}_{4}\right)$ was obtained (Figures 5 and 6).

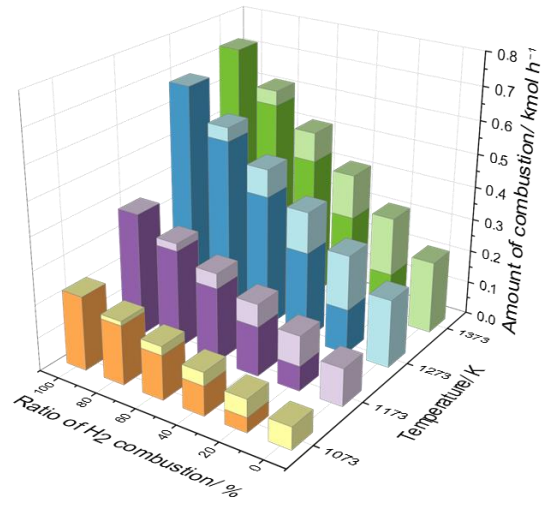

(a)

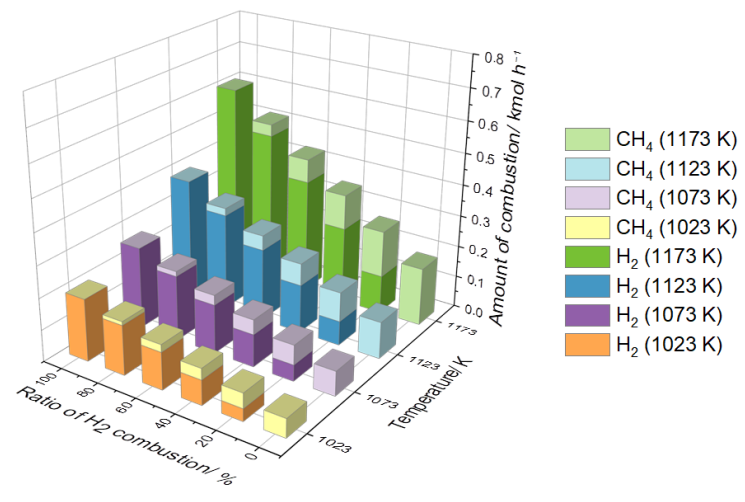

(b)

Figure 5. Amount of fuel $\left(\mathrm{CH}_{4}\right.$ and $\left.\mathrm{H}_{2}\right)$ consumption for methane pyrolysis (MP) systems of (a) thermal methane pyrolysis (TMP-S1) and (b) catalytic methane pyrolysis (CMP-S2) in temperature of 1073-1373 K and 1023-1173 K.

Figure 5 shows the required amount of fuel in TMP-S1 and CMP-S2 according to temperature and the ratio of $\mathrm{H}_{2}$ combustion $(0 \%, 20 \%, 40 \%, 60 \%, 80 \%$, and $100 \%)$. From the process simulation, the total amount of heat required of $3425,5739,10,380$, and $11,079 \mathrm{cal} \mathrm{s}^{-1}$ for TMP-S1 were needed at $1073 \mathrm{~K}, 1173 \mathrm{~K}, 1273 \mathrm{~K}$, and $1373 \mathrm{~K}$, respectively, and that of 3016, 3941, 5868, and $9246 \mathrm{cal} \mathrm{s}^{-1}$ for CMP-S2 were needed at $1023 \mathrm{~K}, 1073 \mathrm{~K}, 1123 \mathrm{~K}$, and 
$1173 \mathrm{~K}$, respectively, showing the higher amount of heat is needed for TMP-S1 than CMP-S2 due to its higher reaction temperature and the technical benefit of the catalyst-based MP.

For TMP-S1, the amounts of $\mathrm{CH}_{4}$ consumption were estimated as $0.07,0.11,0.21$, and $0.22 \mathrm{kmol} \mathrm{h}^{-1}$ and the amounts of $\mathrm{H}_{2}$ consumption of $0.22,0.37,0.67$, and $0.72 \mathrm{kmol} \mathrm{h}^{-1}$ were obtained when $\mathrm{CH}_{4}$ and $\mathrm{H}_{2}$ covered the total amount of heat required, respectively, showing an increasing trend as temperature increased. Similarly, for CMP-S2, $0.06-0.18 \mathrm{kmol} \mathrm{h}^{-1}$ of $\mathrm{CH}_{4}$ consumption and $0.20-0.60 \mathrm{kmol} \mathrm{h}^{-1}$ of $\mathrm{H}_{2}$ consumption were estimated when each type of fuel totally covered the required heat.
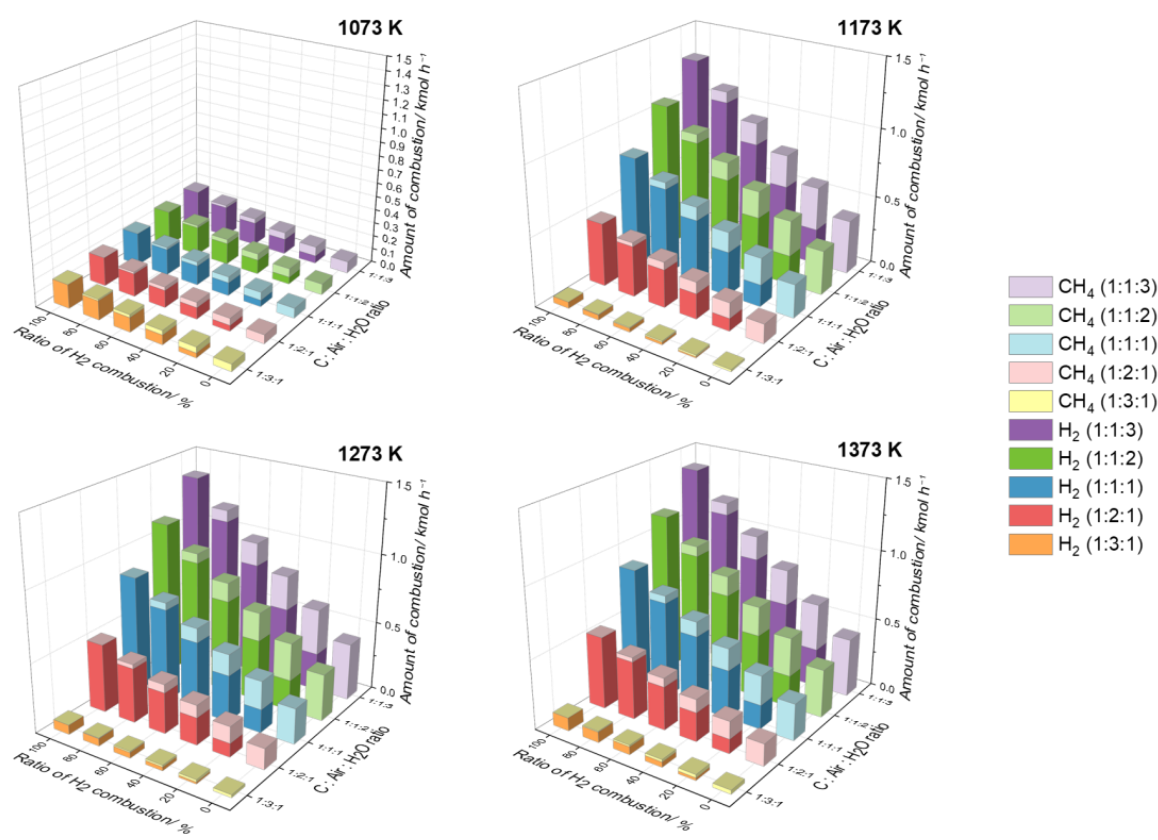

(a)
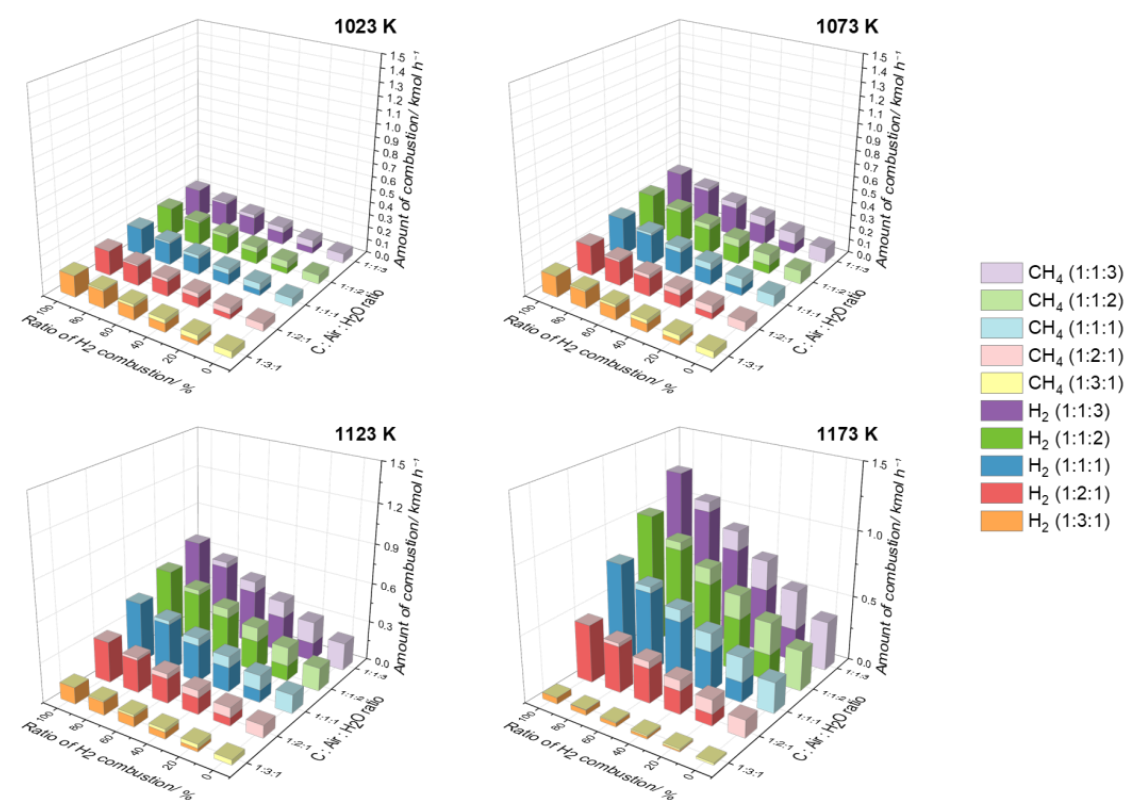

(b)

Figure 6. Amount of fuel $\left(\mathrm{CH}_{4}\right.$ and $\left.\mathrm{H}_{2}\right)$ consumption for methane pyrolysis (MP) systems of thermal and catalytic methane pyrolysis with gasification and WGS reaction ((a) TMPG-S3 and (b) CMPG-S4) in temperature of 1073-1373 K and $1023-1173 \mathrm{~K}$. 
In Figure 6, the amount of required fuel to supply heat for TMPG-S3 and CMPG-S4 is shown. In TMPG-S3 and CMPG-S4, much larger amounts of heat of 2691-4330, 725-19852, 1047-20,821, and 1464-21,245 cal s ${ }^{-1}$ for TMPG-S3 and 2503-3643, 2442-5737, 1925-10,514, and 745-18,954 cal s ${ }^{-1}$ for CMPG-S4 were obtained as the temperature increased, showing much greater increase than previous systems due to the additional endothermic process of $C$ gasification. For both systems in particular, the ratio of reactants of 1:1:3 showed the highest amount of heat required compared with other ratios due to its high reaction extent, represented by high $\mathrm{H}_{2}$ and $\mathrm{C}$ production rates in Figure 4 . In addition, the very high impact of $\mathrm{H}_{2} \mathrm{O}$ in the amount of heat required was confirmed again with trends of the required fuel at different ratios of reactants for the gasifier.

For TMPG-S3, the amount of $\mathrm{CH}_{4}$ fuel required of $0.01-0.42 \mathrm{kmol} \mathrm{h}^{-1}$ when it covers total heat required can be replaced by the amount of $\mathrm{H}_{2}$ combusted of $0.05-1.39 \mathrm{kmol} \mathrm{h}^{-1}$; for CMPG-S4, the $\mathrm{H}_{2}$ consumption range of $0.05-1.24 \mathrm{kmol} \mathrm{h}^{-1}$ was estimated to replace the amount of $\mathrm{CH}_{4}$ required of $0.01-0.37 \mathrm{kmol} \mathrm{h}^{-1}$.

\subsection{Itemized Cost Estimation}

Based on the results from the process simulation, the itemized cost estimation for each MP system using only $\mathrm{CH}_{4}$ and $\mathrm{H}_{2}$ as fuel was conducted to investigate unit $\mathrm{H}_{2}$ production cost at the temperature of $1273 \mathrm{~K}$ for TMP-S1 and TMPG-S3 and $1173 \mathrm{~K}$ for CMP-S2 and CMPG-S4, with the ratio of $\mathrm{H}_{2}$ combusted of $40 \%$, and the ratio of reactants for the gasifier of 1:1:2 (C-Air- $\left.\mathrm{H}_{2} \mathrm{O}\right)$ (Table 3).

Table 3. Results of itemized cost estimation for methane pyrolysis (MP) systems of (a) thermal methane pyrolysis (TMP-S1), (b) catalytic methane pyrolysis (CMP-S2), and systems with additional gasification and WGS reaction of (c) TMPG-S3 and (d) CMPG-S4.

\begin{tabular}{|c|c|c|c|c|c|c|c|c|}
\hline \multirow[b]{2}{*}{ Items } & \multicolumn{2}{|c|}{ (a) TMP-S1 } & \multicolumn{2}{|c|}{ (b) CMP-S2 } & \multicolumn{2}{|c|}{ (c) TMPG-S3 } & \multicolumn{2}{|c|}{ (d) CMPG-S4 } \\
\hline & $\begin{array}{c}\text { Annualized } \\
\text { Cost/USD y }\end{array}$ & $\begin{array}{c}\text { Unit } \mathrm{H}_{2} \\
\text { Production } \\
\text { Cost/USD } \\
\mathrm{kgH}_{2}{ }^{-1}\end{array}$ & $\begin{array}{l}\text { Annualized } \\
\text { Cost/USD y } y^{-1}\end{array}$ & $\begin{array}{c}\text { Unit } \mathrm{H}_{2} \\
\text { Production } \\
\text { Cost/USD } \\
\mathrm{kgH}_{2}{ }^{-1}\end{array}$ & $\begin{array}{c}\text { Annualized } \\
\text { Cost/USD y }{ }^{-1}\end{array}$ & $\begin{array}{c}\text { Unit } \mathrm{H}_{2} \\
\text { Production } \\
\text { Cost/USD } \\
\mathrm{kgH}_{2}{ }^{-1}\end{array}$ & $\begin{array}{c}\text { Annualized } \\
\text { Cost/USD y }{ }^{-1}\end{array}$ & $\begin{array}{c}\text { Unit } \mathrm{H}_{2} \\
\text { Production } \\
\text { Cost/ } \\
\text { USD } \mathrm{kgH}_{2}{ }^{-1}\end{array}$ \\
\hline \multicolumn{9}{|l|}{ 1. Capital cost } \\
\hline MP reactor & 37,139 & 1.29 & 35,590 & 1.33 & 50,967 & 1.05 & 48,840 & 1.08 \\
\hline WGS reactor & - & - & - & - & 1804 & 0.04 & 1729 & 0.04 \\
\hline Regenerator & - & - & 19,233 & 0.72 & - & - & - & - \\
\hline Catalyst & - & - & 6 & 0.00 & - & - & 6 & 0.00 \\
\hline Gasifier & - & - & - & - & 6452 & 0.13 & 6183 & 0.14 \\
\hline PSA & 11,323 & 0.39 & 17,924 & 0.67 & 21,320 & 0.44 & 25,460 & 0.56 \\
\hline Cyclone & 224 & 0.01 & 214 & 0.01 & 224 & 0.00 & 213 & 0.00 \\
\hline Supplement & 8833 & 0.31 & 11,665 & 0.44 & 13,819 & 0.28 & 13,854 & 0.31 \\
\hline \multicolumn{9}{|l|}{$\begin{array}{l}\text { 2. Operating } \\
\text { cost }\end{array}$} \\
\hline Reactant & 33,704 & 1.17 & 33,704 & 1.26 & 33,704 & 0.69 & 33,704 & 0.74 \\
\hline $\begin{array}{c}\text { Catalyst } \\
\text { operating cost }\end{array}$ & - & - & 6 & 0.00 & - & - & 6 & 0.00 \\
\hline Water & - & - & - & - & 2448 & 0.05 & 2251 & 0.05 \\
\hline Fuel & 4150 & 0.14 & 3696 & 0.14 & 6848 & 0.14 & 6189 & 0.14 \\
\hline Labor & 7524 & 0.26 & 7524 & 0.28 & 7524 & 0.15 & 7524 & 0.17 \\
\hline $\begin{array}{l}\text { PSA operating } \\
\text { cost }\end{array}$ & 2 & 0.00 & 183 & 0.01 & 178 & 0.00 & 341 & 0.01 \\
\hline Maintenance & 11,489 & 0.40 & 15,173 & 0.57 & 17,975 & 0.37 & 18,021 & 0.40 \\
\hline Other costs & 5745 & 0.20 & 7587 & 0.28 & 8988 & 0.18 & 9011 & 0.20 \\
\hline $\begin{array}{l}\text { 3. } C \text { selling } \\
\text { price }\end{array}$ & $-58,700$ & -2.04 & $-54,352$ & -2.03 & - & - & - & - \\
\hline 4. Total cost & 61,431 & 2.14 & 98,152 & 3.66 & 172,250 & 3.53 & 173,332 & 3.82 \\
\hline
\end{tabular}


For TMP-S1, unit $\mathrm{H}_{2}$ production cost of USD $2.14 \mathrm{kgH}_{2}{ }^{-1}$ was estimated considering the capital cost of the MP reactor, PSA, cyclone, and supplement, and the operating cost of reactant, fuel, labor, PSA operating cost, maintenance, and other costs. In this estimation, the costs of the MP reactor and reactant account for $31 \%$ and $28 \%$ of the production cost with no consideration of the $\mathrm{C}$ selling price (USD $4.17 \mathrm{kgH}_{2}{ }^{-1}$ ), respectively, showing its high importance in the economic feasibility. For CMP-S2, unit $\mathrm{H}_{2}$ production cost of USD $3.66 \mathrm{kgH}_{2}{ }^{-1}$ was estimated with additional items related to a catalyst such as the cost of the regenerator and catalyst, and its operating cost. Among economic parameters, it is clear that the costs of the MP reactor and reactant are the most influential economic factors, showing high ratios of $23 \%$ and $22 \%$ of the production cost without considering the $\mathrm{C}$ selling price (USD $5.69 \mathrm{kgH}_{2}{ }^{-1}$ ). In both TMP-S1 and CMP-S2, where units of the gasifier and WGS reactor were not constructed in the process simulation, the cost of the MP reactor and reactant and the $\mathrm{C}$ selling price have a very high economic impact on $\mathrm{H}_{2}$ production.

For TMPG-S3 and CMPG-S4, additional economic parameters related to the gasification of $C$ and the WGS reaction means that the costs of the WGS reactor, gasifier, and water were considered and compared to both TMP-S1 and CMP-S2. For both systems, the relatively increased unit $\mathrm{H}_{2}$ production costs of USD 3.53 and $3.82 \mathrm{kgH}_{2}{ }^{-1}$ for TMPG-S3 and CMPG-S4, respectively, were estimated compared to those of USD 2.14 and $3.66 \mathrm{kgH}_{2}{ }^{-1}$ for TMP-S1 and CMP-S2, respectively. In addition, similar to TMP-S1 and CMP-S2, costs of the MP reactor and reactant were found to be the most influential economic parameters showing portions of $30 \%$ and $19 \%$, and $28 \%$ and $19 \%$ for TMPG-S3 and CMPG-S4, respectively.

Our results indicated that the selling of $C$ can be a very effective way to obtain economic competitiveness through the concept of MP, and showed the importance of the cost of the MP reactor and reactant for economic feasibility.

\subsection{Parametric Study-Economic Aspects}

To investigate the effects of the important parameters of reaction temperature, the ratio of $\mathrm{H}_{2}$ combusted to supply the heat required in the process, and the ratio of reactants composed of $\mathrm{C}$, Air, and $\mathrm{H}_{2} \mathrm{O}$ for the gasifier on economic feasibility, a comprehensive parametric study revealing trends of unit $\mathrm{H}_{2}$ production cost was conducted (Figure 7).

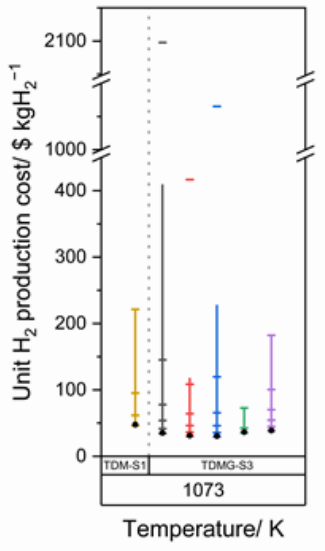

(a)

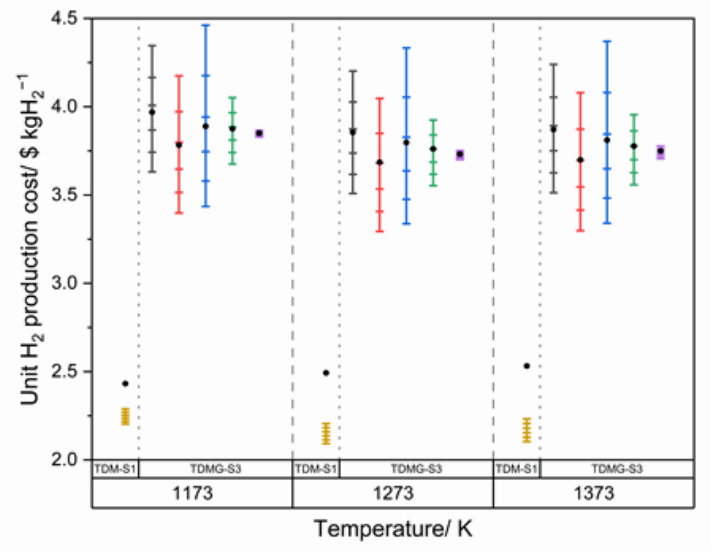

(b)

\begin{tabular}{|l|l|}
\hline $\begin{array}{l}\text { Ratio of } \mathrm{H}_{2} \\
\text { combusted }\end{array}$ & C:Air: $\mathrm{H}_{2} \mathrm{O}$ \\
\hline & \\
\hline & \\
\hline & $0 \%$ \\
$20 \%$ & $1: 1: 1$ \\
$40 \%$ & $1: 1: 2$ \\
$-60 \%$ & $-1: 1: 3$ \\
$-80 \%$ & $-1: 3: 1$ \\
$100 \%$ & - \\
\hline
\end{tabular}

Figure 7. Cont. 


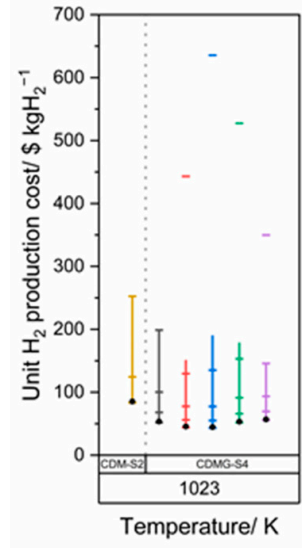

(c)

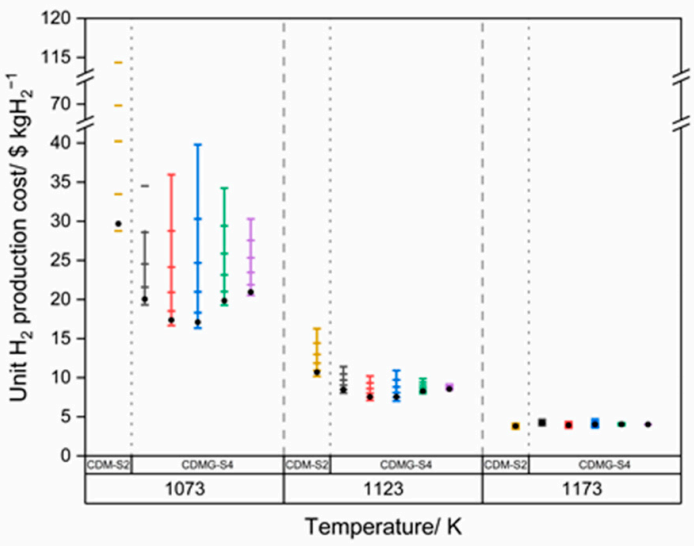

(d)

Figure 7. Unit $\mathrm{H}_{2}$ production cost for methane pyrolysis (MP) systems of (a) thermal methane pyrolysis (TMP-S1), (b) catalytic methane pyrolysis (CMP-S2), and the systems with additional gasification and WGS reaction of (c) TMPG-S3 and (d) CMPG-S4.

In the case of low temperature use where $1073 \mathrm{~K}$ for thermal-based systems (TMPS1 and TMPG-S3) and $1023 \mathrm{~K}$ for catalyst-based systems (CMP-S2 and CMPG-S4) were considered, there were no economic benefits in either system. The minimum unit $\mathrm{H}_{2}$ production costs of USD $46.09 \mathrm{kgH}_{2}{ }^{-1}$ (TMP-S1) and USD 29.48-38.06 $\mathrm{kgH}_{2}{ }^{-1}$ (TMPG-S3) for thermal-based systems and USD $83.40 \mathrm{kgH}_{2}{ }^{-1}$ (CMP-S2) and USD 43.11-55.56 $\mathrm{kgH}_{2}{ }^{-1}$ (CMPG-S4) for catalyst-based systems were reported. In addition, for the case of using electricity as the heat source, the cost was slightly higher but almost the same as the lowest cost using fuel combustion for both the thermal-based and catalyst-based system. Therefore, it is advantageous to use electricity as a heat source at low temperatures, but it still seems it would be difficult to gain economic benefits because of the high production costs.

In cases of high temperature, where 1173-1373 K for thermal-based systems and 1073-1173 K for catalyst-based systems were studied, cost reductions as temperature increased were shown. For TMP-S1, as temperature increased unit $\mathrm{H}_{2}$ production costs of USD 2.20-2.29, 2.09-2.21, and 2.10-2.23 $\mathrm{kgH}_{2}{ }^{-1}$ and a cost reduction of $5.03 \%$ for each minimum cost were reported, which are much cheaper than the minimum costs for TMPGS3 of USD 3.40, 3.29, and $3.30 \mathrm{kgH}_{2}{ }^{-1}$, proving the economic weakness of adopting the additional $\mathrm{H}_{2}$ production processes of $\mathrm{C}$ gasification and WGS reaction. Interestingly, the lowest hydrogen production cost was found at temperatures of $1273 \mathrm{~K}$, even though it was not the highest temperature. In addition, for the case of using electricity, the cost for TMP-S1 is much higher at USD 2.43, 2.49, and $2.53 \mathrm{kgH}_{2}{ }^{-1}$ than in the combustion case as temperature increased. However, in TMPG-S3, it shows values of USD 3.78-3.97, 3.69-3.86, and $3.70-3.87 \mathrm{kgH}_{2}{ }^{-1}$ that are close to the average for combustion; thus, electricity can be beneficial as a heat source depending on the ratio of $\mathrm{H}_{2}$ combusted.

Compared to the trend of unit $\mathrm{H}_{2}$ production cost for the thermal-based system, dramatic cost reductions in CMP-S2 were obtained for the catalyst-based system showing decreased unit $\mathrm{H}_{2}$ production costs of USD 28.77-114.35, 10.17-16.28, 3.43-4.16 $\mathrm{kgH}_{2}{ }^{-1}$ due to its technical improvement as temperature increased. In addition, except at the temperature of $1173 \mathrm{~K}$, the economic benefit of the processes for $\mathrm{C}$ gasification and WGS reaction was reported showing lower minimum unit $\mathrm{H}_{2}$ production cost ranges of USD 16.34-20.52 and 7.02-8.42 $\mathrm{kgH}_{2}{ }^{-1}$ for CMPG-S4 than those of USD 28.77 and $10.17 \mathrm{kgH}_{2}{ }^{-1}$ for CMP-S2 at $1073 \mathrm{~K}$ and $1123 \mathrm{~K}$, respectively. In the case of electricity as the heat source, CMP-S2 shows costs of USD 29.68, 10.69, and $3.81 \mathrm{kgH}_{2}{ }^{-1}$ and CMPG-S4 shows costs of USD 17.10-20.95, 7.55-8.55, and 3.93-4.20 $\mathrm{kgH}_{2}{ }^{-1}$ as temperature increased, showing slightly higher costs than the lowest cost using fuel combustion.

From these results, very critical effects, especially for the catalyst-based MP process, of temperature on economic feasibility and the need for the proper adoption of additional $\mathrm{H}_{2}$ production processes can be revealed. 


\subsection{Sensitivity and Scenario Analysis}

To investigate key economic parameters in each system and the possibility of the commercialization of each system, sensitivity and scenario analyses were conducted. In this study, one economic parameter was varied in the range of $\pm 20 \%$ with the remaining parameters fixed, and variations of unit $\mathrm{H}_{2}$ production cost for each system were obtained with key factors showing high variation remarked. Figure $8 \mathrm{a}, \mathrm{b}$ reveal the economic importance of C selling price in both TMP-S1 and CMP-S2 showing very high variations of $19.1 \%$ and $11.1 \%$, respectively. Costs of the MP reactor and reactant were also figured out as the next influential parameters showing variations of $12.1 \%$ and $10.9 \%$, and $7.2 \%$ and $6.9 \%$ for TMPG-S3 and CMPG-S4, respectively. For TMPG-S3 and CMPG-S4, where all C is combusted leading to no profits from the selling of $C$, the same economic parameters of costs of the MP reactor and reactant were reported as the most influential factors with variations of $6.0 \%$ and $3.9 \%$, and $5.6 \%$ and $3.9 \%$, respectively (Figure $8 \mathrm{c}, \mathrm{d}$ ).

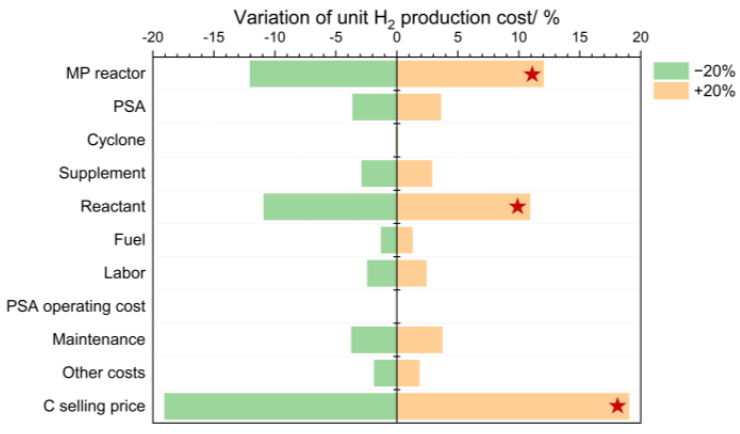

(a)

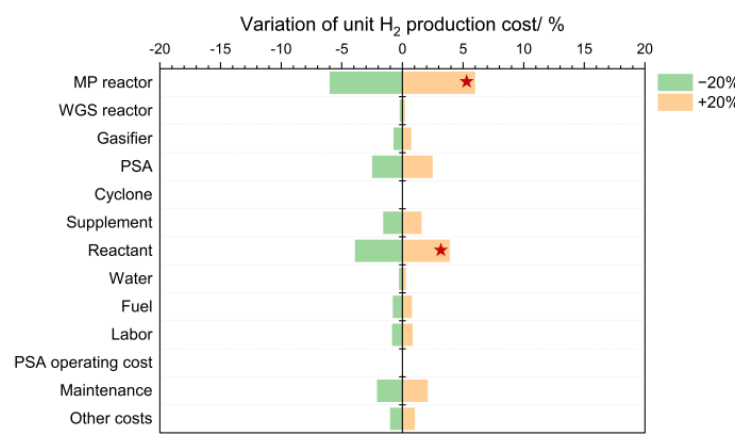

(c)

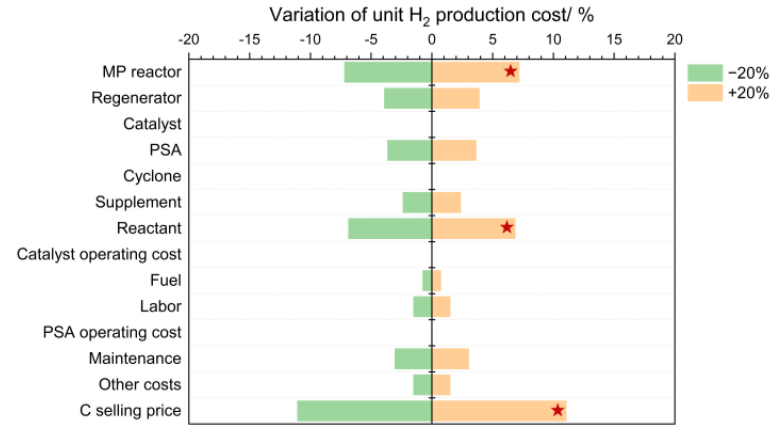

(b)

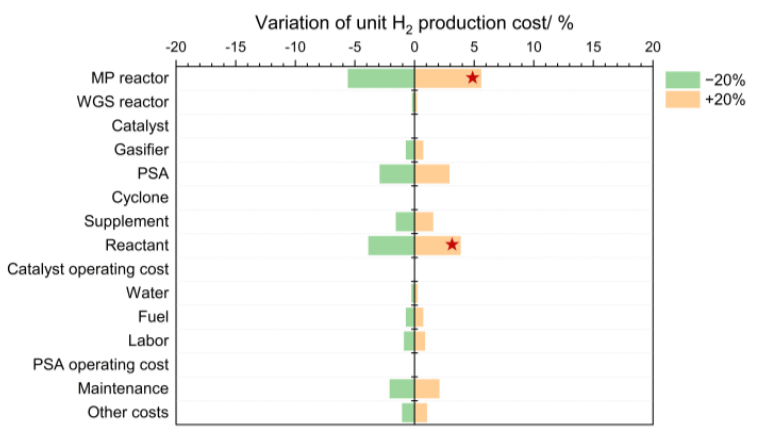

(d)

Figure 8. Results of sensitivity analysis for methane pyrolysis (MP) systems of (a) thermal methane pyrolysis (TMP-S1), (b) catalytic methane pyrolysis (CMP-S2), and the systems with additional gasification and WGS reaction of (c) TMPG-S3 and (d) CMPG-S4.

On the other hand, the scale of certain chemical engineering processes is also known to be a very influential factor to determine their economic feasibility [65]. Therefore, a scenario analysis for $\mathrm{H}_{2}$ production scale, which can lead to a cost reduction in capital cost as reported [66], and the different C selling price in the system of TMP-S1 and CMP-S2, which is a very crucial economic factor as reported by the sensitivity analysis, to reflect a pessimistic price fluctuation and low product quality of $\mathrm{C}$, was conducted and compared to conventional $\mathrm{H}_{2}$ production methods of SMR (USD 0.94-1.78 $\mathrm{kgH}_{2}{ }^{-1}$ ) and SMR with CCS (USD 1.45-2.38 $\mathrm{kgH}_{2}{ }^{-1}$ ) [67] (Figure 9). As shown in Figure 9, there was a clear cost reduction as the $\mathrm{H}_{2}$ production scale increased due to the economics of scale. For CMPG-S4, unit $\mathrm{H}_{2}$ production cost decreased from USD 3.82 to $1.99 \mathrm{kgH}_{2}^{-1}(-47.9 \%)$ proving it can compete in price with SMR+CCS but not with SMR. Similarly, larger cost reductions of $51.6 \%$ and $60.7 \%$ were obtained for TMP-S1 and CMP-S2, respectively, with no C selling 
price assumed (represented by USD 0 ton $^{-1}$ ), which are still not enough to compete with conventional $\mathrm{H}_{2}$ production methods of SMR.

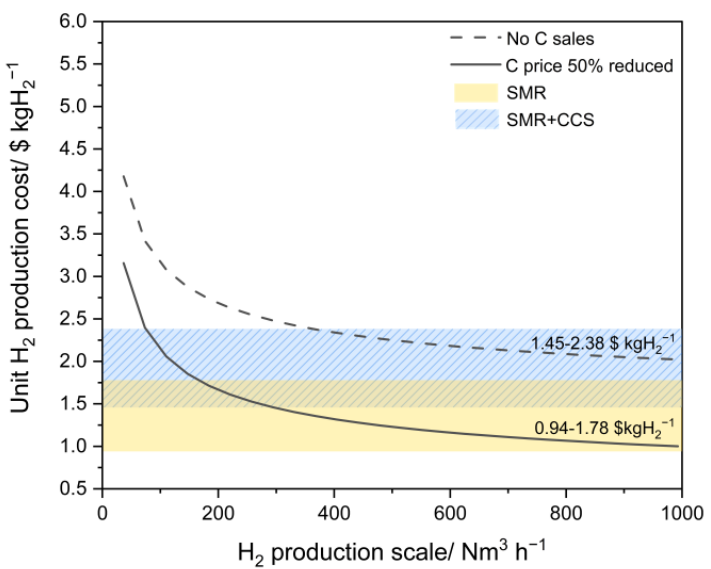

(a)

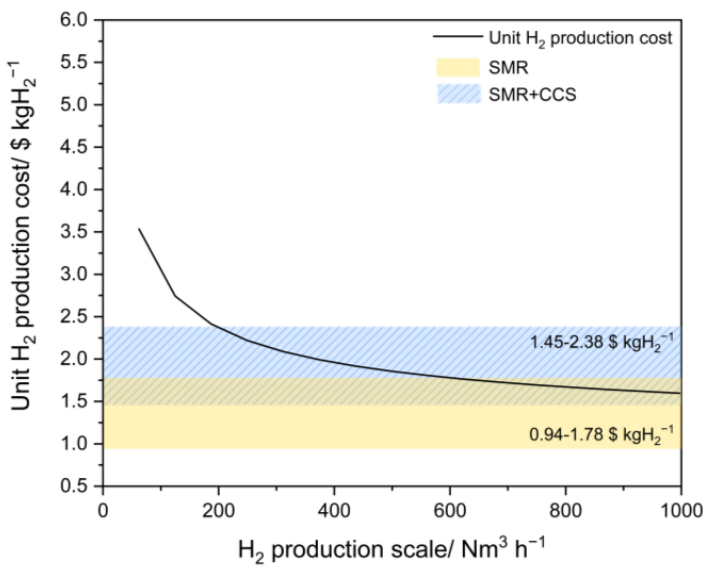

(c)

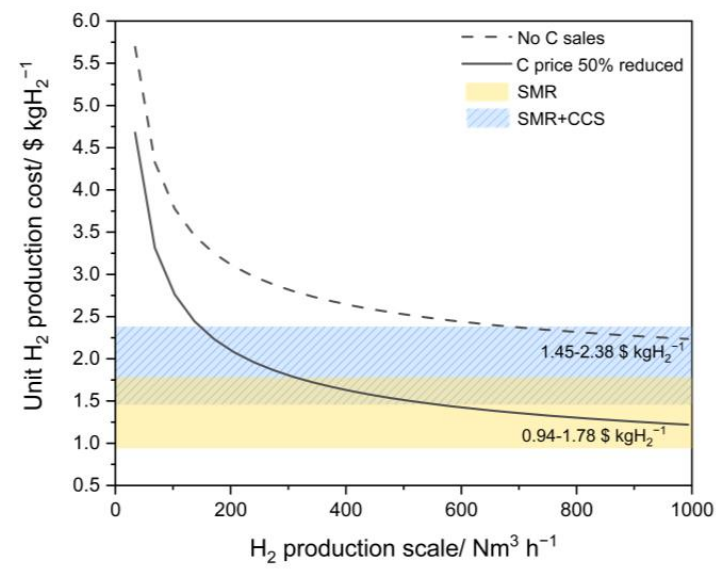

(b)

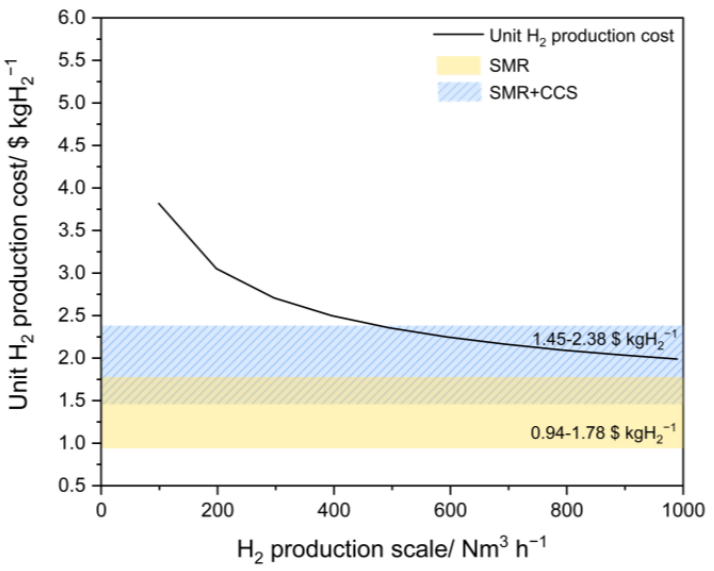

(d)

Figure 9. Results of scenario analysis up to $1000 \mathrm{Nm}^{3} \mathrm{~h}^{-1}$ for methane pyrolysis (MP) systems of (a) thermal methane pyrolysis (TMP-S1), (b) catalytic methane pyrolysis (CMP-S2), and the systems with additional gasification and WGS reaction of (c) TMPG-S3 and (d) CMPG-S4 with comparison to systems of steam methane reforming (SMR) of USD 0.94-1.78 $\mathrm{kgH}_{2}{ }^{-1}$ and SMR with carbon capture and storage (CCS) of USD 1.45-2.38 $\mathrm{kgH}_{2}{ }^{-1}$.

However, for TMP-S1 and CMP-S2, with a C selling price of EUR 250 ton $^{-1}$ (-50\% of the assumed $\mathrm{C}$ selling price) and for TMPG-S3, with unit $\mathrm{H}_{2}$ production costs decreased from USD 3.16 to $1.00 \mathrm{kgH}_{2}{ }^{-1}$, USD 4.68 to $1.22 \mathrm{kgH}_{2}{ }^{-1}$, and USD 3.53 to $1.60 \mathrm{kgH}_{2}{ }^{-1}$ showing reductions of $68.3 \%, 73.9 \%$ and $54.8 \%$, respectively, proving their economic competitiveness with conventional commercialized $\mathrm{H}_{2}$ production methods of SMR and SMR with CCS.

In short, the key economic parameters of $C$ selling price and costs of MP reactor and reactant were calculated and the future economic competitiveness for all systems with high $\mathrm{H}_{2}$ production scales and $\mathrm{C}$ selling prices, even pessimistic prices, was confirmed.

\section{Conclusions}

The promising alternative clean concept of $\mathrm{H}_{2}$ production of methane pyrolysis (MP) was technically and economically investigated by preliminary techno-economic analysis consisting of a process simulation using Aspen Plus ${ }^{\circledR}$, itemized cost estimation, and sensitivity and scenario analysis for various parameters such as temperature, the ratio of fuel $\left(\mathrm{CH}_{4}\right.$ and $\mathrm{H}_{2}$ produced from $\left.\mathrm{MP}\right)$ combusted, and the ratio of reactants for $\mathrm{C}$ gasification 
(C, Air, and $\mathrm{H}_{2} \mathrm{O}$ ). To investigate various $\mathrm{H}_{2}$ production scenarios, thermal and catalytic methane pyrolysis (TMP-S1 and CMP-S2) and systems with additional $\mathrm{H}_{2}$ production processes composed of $\mathrm{C}$ gasification and WGS reaction (TMPG-S3 and CMPG-S4) were considered in this study. The results of the process simulation indicated that reaction temperature is the most influential process variable for determining the technical performance of all investigated systems, and catalyst-based MP (CMP-S2 and CMPG-S4) showed much lower net $\mathrm{H}_{2}$ and $\mathrm{C}$ production rates than thermal-based systems (TMP-S1 and TMPG-S3), where theoretical maximum yields were obtained, due to different kinetics used in the simulation. In addition, the amount of $\mathrm{H}_{2} \mathrm{O}$ added in TMPG-S3 and CMPG-S4 was reported as the most important factor to increase the amount of $\mathrm{H}_{2}$ produced. For an aspect of fuel consumption estimated from the amount of heat required for each system, trends similar to the net $\mathrm{H}_{2}$ and $\mathrm{C}$ production were obtained showing the amounts of heat of 3425-11,079 $\mathrm{cal} \mathrm{s}^{-1}$ for TMP-S1, 3016-9246 $\mathrm{cal} \mathrm{s}^{-1}$ for CMP-S2, 725-21,245 cal $\mathrm{s}^{-1}$ for TMPG-S3, and 744-18,945 $\mathrm{cal} \mathrm{s}^{-1}$ for CMPG-S4 matched with the required fuel amounts of $0.068-0.219,0.060-0.183,0.014-0.420$, and $0.015-0.375 \mathrm{kmol} \mathrm{h}^{-1}$ and $0.223-0.723$, $0.197-0.603,0.047-1.386,0.049-1.236 \mathrm{kmol} \mathrm{h}^{-1}$ for $\mathrm{CH}_{4}$ and $\mathrm{H}_{2}$, respectively. From the itemized cost estimation for each system at $1273 \mathrm{~K}$ for TMP-S1 and TMPG-S3 and $1173 \mathrm{~K}$ for CMP-S2 and CMPG-S4, with $40 \% \mathrm{H}_{2}$ combusted, and the ratio of 1:1:2 for C-Air- $\mathrm{H}_{2} \mathrm{O}$, unit $\mathrm{H}_{2}$ production costs of USD 2.14, 3.66, 3.53, and $3.82 \mathrm{gH}_{2}{ }^{-1}$ for each system, respectively, were obtained showing a very high portion of the costs of the MP reactor and reactant, and the economic benefits of the carbon (C) selling price. To investigate the effects of each parameter of temperature, the ratio of fuel combusted, and ratios of $\mathrm{C}$, Air, and $\mathrm{H}_{2} \mathrm{O}$ on economic feasibility, a parametric study was conducted proving the economic benefits of high temperature and the additional $\mathrm{H}_{2}$ production process of $\mathrm{C}$ gasification and WGS reaction for CMPG-S4 but not for thermal-based MP process. The importance of the costs of the MP reactor and reactant and the $\mathrm{C}$ selling price for economic feasibility was calculated again by sensitivity analysis, where the variation of $\pm 20 \%$ was assumed, with variations of unit $\mathrm{H}_{2}$ production cost of $19.1 \%$ and $11.1 \%$ for $\mathrm{C}$ selling price in TMP-S1 and CMP-S2, respectively, and $12.1 \%-5.6 \%$ and $10.9 \%-3.9 \%$ for costs of the MP reactor and reactant, respectively, in all investigated systems. In addition, the effects of $\mathrm{H}_{2}$ production scale for all systems and the $\mathrm{C}$ selling price for TMP-S1 and CMP-S2 on the unit $\mathrm{H}_{2}$ production costs were investigated suggesting that all systems can compete with SMR with CCS, and especially TMP-S1 and CMP-S2, even with the pessimistic 50\% reduced C selling price; for TMPG-S3, economic competitiveness with the commercialized $\mathrm{H}_{2}$ production method of SMR can be achieved when an $\mathrm{H}_{2}$ production scale larger than $1000 \mathrm{Nm}^{3} \mathrm{~h}^{-1}$ is assumed.

Conclusively, the techno-economic feasibility of MP processes, classified as the four systems of TMP-S1, CMP-S2, TMPG-S3, and CMPG-S4, was investigated with detailed $\mathrm{H}_{2}$ and $C$ production rates, the amount of fuel required to supply heat in each system, the trends of unit $\mathrm{H}_{2}$ production cost according to temperature, the ratio of $\mathrm{H}_{2}$ combusted, and the ratio of reactants used in the $\mathrm{C}$ gasifier, and revealed key economic parameters of the costs of the MP reactor and reactant and the $\mathrm{C}$ selling price. Although several technoeconomic enhancements such as scale-up should be researched further to accomplish the economic competitiveness of MP compared to SMR, the environmental benefits of MP are clearly shown in this study based on its theoretical reaction stoichiometry and trends of its consumption of fuels. Based on the results, the potential of both thermal and catalytic MP for promising $\mathrm{H}_{2}$ production is clearly presented.

Author Contributions: Conceptualization, H.L. (Hankwon Lim) and S.C.; methodology, S.C. and M.B.; validation, M.B.; investigation, D.L. and H.L. (Hyunjun Lee); writing-original draft preparation, S.C. and M.B.; writing-review and editing, S.C. and M.B.; supervision, H.L. (Hankwon Lim); funding acquisition, H.L. (Hankwon Lim). All authors have read and agreed to the published version of the manuscript.

Funding: This work was supported by the Korea Institute of Energy Technology Evaluation and Planning (KETEP) and the Ministry of Trade, Industry and Energy (MOTIE) of the Republic of Korea 
(No. 20203020040010) and supported by the 2021 Research Fund (1.210103.01) of UNIST (Ulsan National Institute of Science and Technology).

Institutional Review Board Statement: Not applicable.

Informed Consent Statement: Not applicable.

Data Availability Statement: Not applicable.

Conflicts of Interest: The authors declare no conflict of interest.

\section{Nomenclature}

$\begin{array}{ll}\mathrm{CO}_{2} & \text { Carbon dioxide } \\ \mathrm{CO} & \text { Carbon monoxide } \\ \mathrm{CCS} & \text { Carbon capture and storage } \\ \mathrm{CMP} & \text { Catalytic methane pyrolysis } \\ \mathrm{CMPG} & \text { Catalytic methane pyrolysis with carbon gasification } \\ \mathrm{CRF} & \text { Capital recovery factor } \\ \mathrm{CEPCI} & \text { Chemical engineering plant cost index } \\ \mathrm{MP} & \text { Methane pyrolysis } \\ \mathrm{FLBR} & \text { Fluidized bed reactor } \\ \mathrm{GHG} & \text { Greenhouse gas } \\ \mathrm{H}_{2} & \text { Hydrogen } \\ \mathrm{CH} & \text { Methane } \\ \mathrm{PSA} & \text { Pressure swing adsorption } \\ \mathrm{SMR} & \text { Steam methane reforming } \\ \mathrm{SMR} \text { with CCS } & \text { Steam methane reforming with carbon capture and storage } \\ \mathrm{TMP} & \text { Thermal methane pyrolysis } \\ \text { TMPG } & \text { Thermal methane pyrolysis with carbon gasification } \\ \text { VPMDCS } & \text { Vacuum promote methane decomposition with carbon separation } \\ \mathrm{H}_{2} \mathrm{O} & \text { Water } \\ \text { WE } & \text { Water electrolysis } \\ \text { WGS } & \text { Water-gas shift }\end{array}$

\section{References}

1. Federal Ministry for Economic Affairs and Energy. Available online: https://www.bmwi.de/Redaktion/EN/Publikationen/ Energie/the-national-hydrogen-strategy.html (accessed on 20 July 2021).

2. European Commission. Available online: https://ec.europa.eu/energy/topics/energy-system-integration/hydrogen_en\#euhydrogen-strategy (accessed on 20 July 2021).

3. Ministry of Economy, Trade and Industry. 2017. Available online: https://www.meti.go.jp/english/press/2017/1226_003.html (accessed on 20 July 2021).

4. Ministry of Economy, Trade and Industry. 2018. Available online: https://www.meti.go.jp/english/press/2018/0703_002.html (accessed on 20 July 2021).

5. Ministry of Economy, Trade and Industry. 2019. Available online: https://www.meti.go.jp/english/press/2019/0312_002.html (accessed on 20 July 2021).

6. Climate Change Committee. Available online: https://www.theccc.org.uk/publication/hydrogen-in-a-low-carbon-economy/ (accessed on 20 July 2021).

7. U.S. Department of Energy. Available online: https://www.energy.gov/eere/fuelcells/h2scale (accessed on 20 July 2021).

8. The Commonwealth Scientific and Industrial Research Organisation (CSIRO). Available online: https://www.csiro.au/en/ work-with-us/services/consultancy-strategic-advice-services/csiro-futures/futures-reports/hydrogen-roadmap (accessed on 20 July 2021).

9. Nikolaidis, P.; Poullikkas, A. A comparative overview of hydrogen production processes. Renew. Sustain. Energy Rev. 2017, 67, 597-611. [CrossRef]

10. Mazloomi, K.; Gomes, C. Hydrogen as an energy carrier: Prospects and challenges. Renew. Sustain. Energy Rev. 2012, 16, 3024-3033. [CrossRef]

11. Dawood, F.; Anda, M.; Shafiullah, G. Hydrogen production for energy: An overview. Int. J. Hydrog. Energy 2020, 45, 3847-3869. [CrossRef]

12. Staffell, I.; Scamman, D.; Abad, A.V.; Balcombe, P.; Dodds, P.E.; Ekins, P.; Shah, N.; Ward, K.R. The role of hydrogen and fuel cells in the global energy system. Energy Environ. Sci. 2019, 12, 463-491. [CrossRef] 
13. Acar, C.; Dincer, I. Review and evaluation of hydrogen production options for better environment. J. Clean. Prod. 2019, 218, 835-849. [CrossRef]

14. Reuß, M.; Grube, T.; Robinius, M.; Preuster, P.; Wasserscheid, P.; Stolten, D. Seasonal storage and alternative carriers: A flexible hydrogen supply chain model. Appl. Energy 2017, 200, 290-302. [CrossRef]

15. Tuomi, S.; Santasalo-Aarnio, A.; Kanninen, P.; Kallio, T. Hydrogen production by methanol-Water solution electrolysis with an alkaline membrane cell. J. Power Sources 2013, 229, 32-35. [CrossRef]

16. Lee, B.; Heo, J.; Kim, S.; Sung, C.; Moon, C.; Moon, S.; Lim, H. Economic feasibility studies of high pressure PEM water electrolysis for distributed H2 refueling stations. Energy Convers. Manag. 2018, 162, 139-144. [CrossRef]

17. Ishaq, H.; Dincer, I. Comparative assessment of renewable energy-based hydrogen production methods. Renew. Sustain. Energy Rev. 2020, 135, 110192. [CrossRef]

18. Parkinson, B.; Balcombe, P.; Speirs, J.F.; Hawkes, A.D.; Hellgardt, K. Levelized cost of $\mathrm{CO}_{2}$ mitigation from hydrogen production routes. Energy Environ. Sci. 2018, 12, 19-40. [CrossRef]

19. Navarro, R.M.; Sánchez-Sánchez, M.C.; Alvarez-Galvan, M.C.; Del Valle, F.; Fierro, J.L.G. Hydrogen production from renewable sources: Biomass and photocatalytic opportunities. Energy Environ. Sci. 2008, 2, 35-54. [CrossRef]

20. Nguyen, T.; Abdin, Z.; Holm, T.; Mérida, W. Grid-connected hydrogen production via large-scale water electrolysis. Energy Convers. Manag. 2019, 200, 112108. [CrossRef]

21. Zhang, C.; Greenblatt, J.B.; Wei, M.; Eichman, J.; Saxena, S.; Muratori, M.; Guerra, O.J. Flexible grid-based electrolysis hydrogen production for fuel cell vehicles reduces costs and greenhouse gas emissions. Appl. Energy 2020, 278, 115651. [CrossRef]

22. Christopher, K.; Dimitrios, R. A review on exergy comparison of hydrogen production methods from renewable energy sources. Energy Environ. Sci. 2012, 5, 6640-6651. [CrossRef]

23. Vincent, I.; Bessarabov, D. Low cost hydrogen production by anion exchange membrane electrolysis: A review. Renew. Sustain. Energy Rev. 2018, 81, 1690-1704. [CrossRef]

24. Hosseini, S.E.; Wahid, M.A. Hydrogen production from renewable and sustainable energy resources: Promising green energy carrier for clean development. Renew. Sustain. Energy Rev. 2016, 57, 850-866. [CrossRef]

25. Stojić, D.L.; Marčeta, M.P.; Sovilj, S.P.; Miljanić, S. Hydrogen generation from water electrolysis-Possibilities of energy saving J. Power Sources 2003, 118, 315-319. [CrossRef]

26. Boot-Handford, M.E.; Abanades, J.C.; Anthony, E.J.; Blunt, M.; Brandani, S.; Mac Dowell, N.; Fernández, J.R.; Ferrari, M.-C.; Gross, R.; Hallett, J.; et al. Carbon capture and storage update. Energy Environ. Sci. 2013, 7, 130-189. [CrossRef]

27. Wilberforce, T.; Baroutaji, A.; Soudan, B.; Al-Alami, A.H.; Olabi, A.G. Outlook of carbon capture technology and challenges Sci. Total Environ. 2018, 657, 56-72. [CrossRef]

28. Bui, M.; Adjiman, C.S.; Bardow, A.; Anthony, E.J.; Boston, A.; Brown, S.; Fennell, P.S.; Fuss, S.; Galindo, A.; Hackett, L.A.; et al. Carbon capture and storage (CCS): The way forward. Energy Environ. Sci. 2018, 11, 1062-1176. [CrossRef]

29. Younessi-Sinaki, M.; Matida, E.A.; Hamdullahpur, F. Kinetic model of homogeneous thermal decomposition of methane and ethane. Int. J. Hydrog. Energy 2009, 34, 3710-3716. [CrossRef]

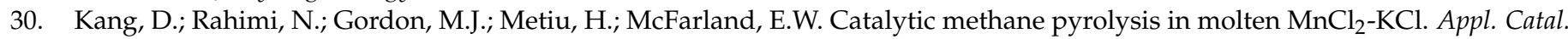
B Environ. 2019, 254, 659-666. [CrossRef]

31. Parfenov, V.E.; Nikitchenko, N.V.; Pimenov, A.A.; Kuz'Min, A.E.; Kulikova, M.V.; Chupichev, O.B.; Maksimov, A.L. Methane Pyrolysis for Hydrogen Production: Specific Features of Using Molten Metals. Russ. J. Appl. Chem. 2020, 93, 625-632. [CrossRef]

32. Bhaskar, A.; Assadi, M.; Somehsaraei, H.N. Can methane pyrolysis based hydrogen production lead to the decarbonisation of iron and steel industry? Energy Convers. Manag. X 2021, 10, 100079. [CrossRef]

33. Fincke, J.R.; Anderson, R.P.; Hyde, T.A.; Detering, B.A. Plasma Pyrolysis of Methane to Hydrogen and Carbon Black. Ind. Eng. Chem. Res. 2002, 41, 1425-1435. [CrossRef]

34. Wang, I.-W.; Kutteri, D.A.; Gao, B.; Tian, H.; Hu, J. Methane Pyrolysis for Carbon Nanotubes and COx-Free H2 over TransitionMetal Catalysts. Energy Fuels 2018, 33, 197-205. [CrossRef]

35. Rahimi, N.; Kang, D.; Gelinas, J.; Menon, A.; Gordon, M.J.; Metiu, H.; McFarland, E.W. Solid carbon production and recovery from high temperature methane pyrolysis in bubble columns containing molten metals and molten salts. Carbon 2019, 151, 181-191. [CrossRef]

36. Farmer, T.C.; McFarland, E.W.; Doherty, M.F. Membrane bubble column reactor model for the production of hydrogen by methane pyrolysis. Int. J. Hydrog. Energy 2019, 44, 14721-14731. [CrossRef]

37. Abbas, H.F.; Daud, W.W. Hydrogen production by methane decomposition: A review. Int. J. Hydrog. Energy 2010, 35, 1160-1190. [CrossRef]

38. Muradov, N. Low to near-zero $\mathrm{CO}_{2}$ production of hydrogen from fossil fuels: Status and perspectives. Int. J. Hydrog. Energy 2017, 42, 14058-14088. [CrossRef]

39. Hu, C.; Shen, H.; Zhang, S.; Li, H. Methane pyrolysis in preparation of pyrolytic carbon: Thermodynamic and kinetic analysis by density functional theory. Chin. J. Aeronaut. 2019, 33, 1064-1073. [CrossRef]

40. Guéret, C.; Daroux, M.; Billaud, F. Methane pyrolysis: Thermodynamics. Chem. Eng. Sci. 1997, 52, 815-827. [CrossRef]

41. Sánchez-Bastardo, N.; Schlögl, R.; Ruland, H. Methane Pyrolysis for $\mathrm{CO}_{2}$-Free $\mathrm{H}_{2}$ Production: A Green Process to Overcome Renewable Energies Unsteadiness. Chem. Ing. Tech. 2020, 92, 1596-1609. [CrossRef] 
42. Nishii, H.; Miyamoto, D.; Umeda, Y.; Hamaguchi, H.; Suzuki, M.; Tanimoto, T.; Harigai, T.; Takikawa, H.; Suda, Y. Catalytic activity of several carbons with different structures for methane decomposition and by-produced carbons. Appl. Surf. Sci. 2018, 473, 291-297. [CrossRef]

43. Tezel, E.; Figen, H.E.; Baykara, S.Z. Hydrogen production by methane decomposition using bimetallic Ni-Fe catalysts. Int. J. Hydrog. Energy 2019, 44, 9930-9940. [CrossRef]

44. Qian, J.X.; Enakonda, L.R.; Wang, W.J.; Gary, D.; Del-Gallo, P.; Basset, J.-M.; Bin Liu, D.; Zhou, L. Optimization of a fluidized bed reactor for methane decomposition over Fe/Al2O3 catalysts: Activity and regeneration studies. Int. J. Hydrog. Energy 2019, 44, 31700-31711. [CrossRef]

45. Patzschke, C.F.; Parkinson, B.; Willis, J.J.; Nandi, P.; Love, A.M.; Raman, S.; Hellgardt, K. Co-Mn catalysts for $\mathrm{H}_{2}$ production via methane pyrolysis in molten salts. Chem. Eng. J. 2021, 414, 128730. [CrossRef]

46. Karaismailoglu, M.; Figen, H.E.; Baykara, S.Z. Hydrogen production by catalytic methane decomposition over yttria doped nickel based catalysts. Int. J. Hydrog. Energy 2019, 44, 9922-9929. [CrossRef]

47. Chen, Z.; Zhang, R.; Xia, G.; Wu, Y.; Li, H.; Sun, Z.; Sun, Z. Vacuum promoted methane decomposition for hydrogen production with carbon separation: Parameter optimization and economic assessment. Energy 2021, 222, 119953. [CrossRef]

48. Riley, J.; Atallah, C.; Siriwardane, R.; Stevens, R. Technoeconomic analysis for hydrogen and carbon Co-Production via catalytic pyrolysis of methane. Int. J. Hydrog. Energy 2021, 46, 20338-20358. [CrossRef]

49. Pérez, B.J.L.; Jiménez, J.A.M.; Bhardwaj, R.; Goetheer, E.; Annaland, M.V.S.; Gallucci, F. Methane pyrolysis in a molten gallium bubble column reactor for sustainable hydrogen production: Proof of concept \& techno-economic assessment. Int. J. Hydrog. Energy 2020, 46, 4917-4935. [CrossRef]

50. Kerscher, F.; Stary, A.; Gleis, S.; Ulrich, A.; Klein, H.; Spliethoff, H. Low-carbon hydrogen production via electron beam plasma methane pyrolysis: Techno-economic analysis and carbon footprint assessment. Int. J. Hydrog. Energy 2021, 46, 19897-19912. [CrossRef]

51. Zhang, X.; Kätelhön, A.; Sorda, G.; Helmin, M.; Rose, M.; Bardow, A.; Madlener, R.; Palkovits, R.; Mitsos, A. CO 2 mitigation costs of catalytic methane decomposition. Energy 2018, 151, 826-838. [CrossRef]

52. Timmerberg, S.; Kaltschmitt, M.; Finkbeiner, M. Hydrog. and hydrogen-derived fuels through methane decomposition of natural gas-GHG emissions and costs. Energy Convers. Manag. X 2020, 7, 100043. [CrossRef]

53. Keipi, T.; Li, T.; Løvås, T.; Tolvanen, H.; Konttinen, J. Methane thermal decomposition in regenerative heat exchanger reactor: Experimental and modeling study. Energy 2017, 135, 823-832. [CrossRef]

54. Kim, M.H.; Lee, E.K.; Jun, J.H.; Kong, S.J.; Han, G.Y.; Lee, B.K.; Lee, T.-J.; Yoon, K.J. Hydrog. production by catalytic decomposition of methane over activated carbons: Kinetic study. Int. J. Hydrog. Energy 2003, 29, 187-193. [CrossRef]

55. Turton, R.; Bailie, R.C.; Whiting, W.B.; Shaeiwitz, J.A.; Bhattacharyya, D. Analysis, Synthesis, and Design of Chemical Processes, 4th ed.; Pearson Education: Upper Saddle River, NJ, UAS, 2013; pp. 157-226.

56. Keipi, T.; Tolvanen, H.; Konttinen, J. Economic analysis of hydrogen production by methane thermal decomposition: Comparison to competing technologies. Energy Convers. Manag. 2018, 159, 264-273. [CrossRef]

57. Vasalos, I.A.; Lappas, A.A.; Kopalidou, E.P.; Kalogiannis, K.G. Biomass catalytic pyrolysis: Process design and economic analysis. Wiley Interdiscip. Rev. Energy Environ. 2016, 5, 370-383. [CrossRef]

58. Liu, L.; Qian, H.; Mu, L.; Wu, J.; Feng, X.; Lu, X.; Zhu, J. Techno-economic analysis of biomass processing with dual outputs of energy and activated carbon. Bioresour. Technol. 2020, 319, 124108. [CrossRef]

59. Hoffman, Z. Simulation and Economic Evaluation of Coal Gasification with SETS Reforming Process for Power Production. Master's Thesis, Louisiana State University (LSU), Baton Rouge, LA, USA, 2005. Available online: https://digitalcommons.lsu. edu/gradschool_theses/2269 (accessed on 21 July 2021).

60. Cruellas, A.; Bakker, J.; Annaland, M.V.S.; Medrano, J.; Gallucci, F. Techno-economic analysis of oxidative coupling of methane: Current state of the art and future perspectives. Energy Convers. Manag. 2019, 198, 111789. [CrossRef]

61. Parkinson, B.; Tabatabaei, M.; Upham, D.C.; Ballinger, B.; Greig, C.; Smart, S.; McFarland, E. Hydrog. production using methane: Techno-economics of decarbonizing fuels and chemicals. Int. J. Hydrog. Energy 2018, 43, 2540-2555. [CrossRef]

62. Chen, J.; Tyagi, R.D.; Li, J.; Zhang, X.; Drogui, P.; Sun, F. Economic assessment of biodiesel production from wastewater sludge. Bioresour. Technol. 2018, 253, 41-48. [CrossRef]

63. Keipi, T.I.-M.; Hankalin, V.; Nummelin, J.; Raiko, R. Techno-economic analysis of four concepts for thermal decomposition of methane: Reduction of $\mathrm{CO}_{2}$ emissions in natural gas combustion. Energy Convers. Manag. 2016, 110, 1-12. [CrossRef]

64. Gim, B.-J.; Kim, J.-W.; Ko, H.-M. Economic evaluation of domestic low-temperature water electrolysis hydrogen production. Trans. Korean Hydrog. New Energy Soc. 2011, 22, 559-567. [CrossRef]

65. Dolan, M.; Beath, A.; Hla, S.; Way, J.; Abu El Hawa, H. An experimental and techno-economic assessment of solar reforming for $\mathrm{H}_{2}$ production. Int. J. Hydrog. Energy 2016, 41, 14583-14595. [CrossRef]

66. Gim, B.; Yoon, W.L. Analysis of the economy of scale and estimation of the future hydrogen production costs at on-site hydrogen refueling stations in Korea. Int. J. Hydrog. Energy 2012, 37, 19138-19145. [CrossRef]

67. International Energy Agency (IEA). Available online: https://www.iea.org/data-and-statistics/charts/hydrogen-productioncosts-using-natural-gas-in-selected-regions-2018-2 (accessed on 25 July 2021). 